EUROPEAN CENTRAL BANK WORKING PAPER SERIES

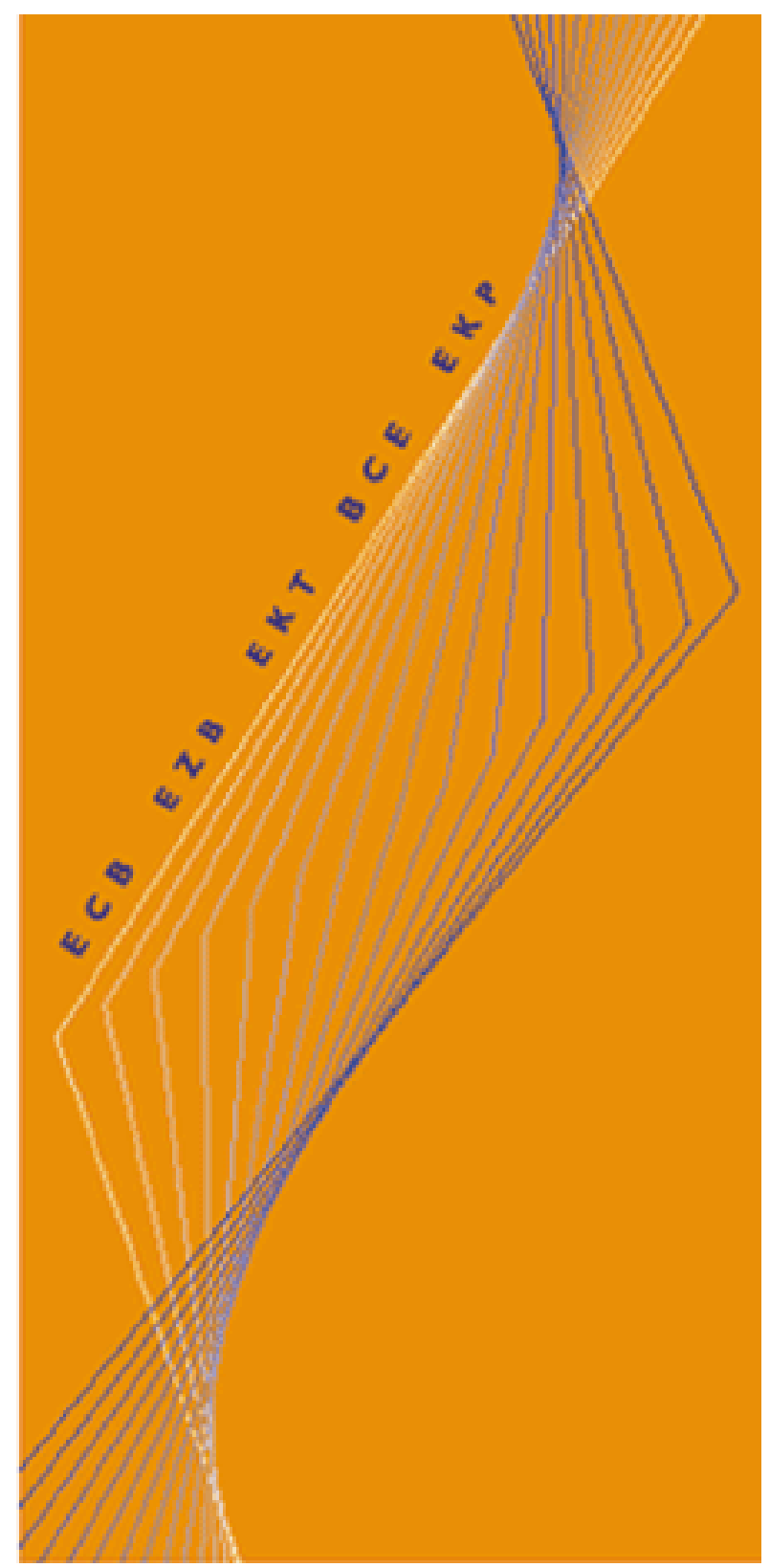

WORKING PAPER NO. I 62

PUBLIC DEBT ASYMMETRIES: THE EFFECT ON TAXES AND SPENDING IN THE EUROPEAN UNION

BY SIGNE KROGSTRUP

August 2002 


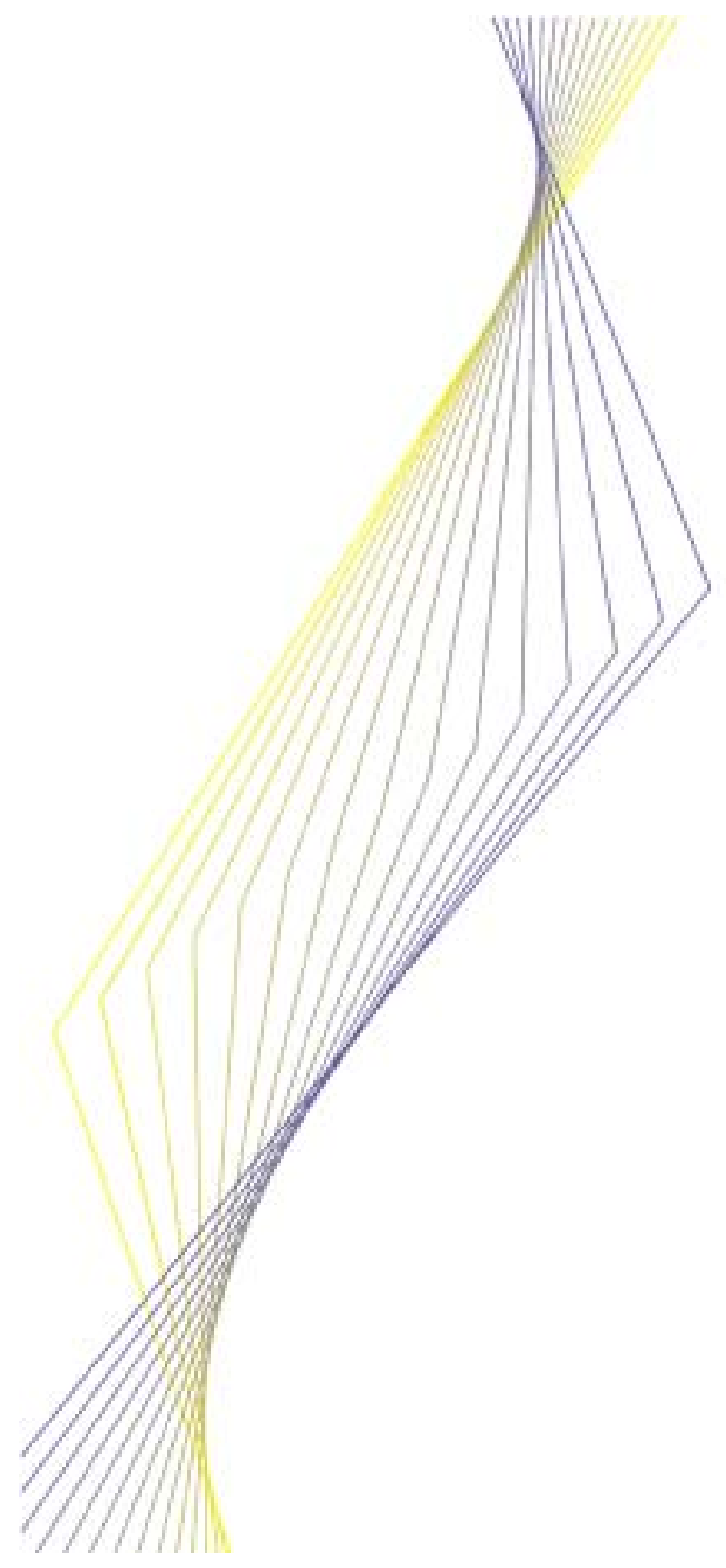

WORKING PAPER NO. I 62

\title{
PUBLIC DEBT ASYMMETRIES: \\ THE EFFECT ON TAXES AND SPENDING IN THE EUROPEAN UNION
}

\author{
BY SIGNE KROGSTRUP*
}

\section{August 2002}

\footnotetext{
* Comments from Rolf Strauch, Charles Wyplosz, Hans Genberg, Jan Lemmen, and an anonymous referee are gratefully acknowledged.This paper was written during a stay at the Fiscal Policies Division of the ECB, Spring 200 I, and I would like to thank everybody in the Division for the excellent work environment as well as the helpful comments on the paper. I would also like to thank David Carey for kindly giving access to his data. The usual disclaimer applies.
} 
(C) European Central Bank, 2002

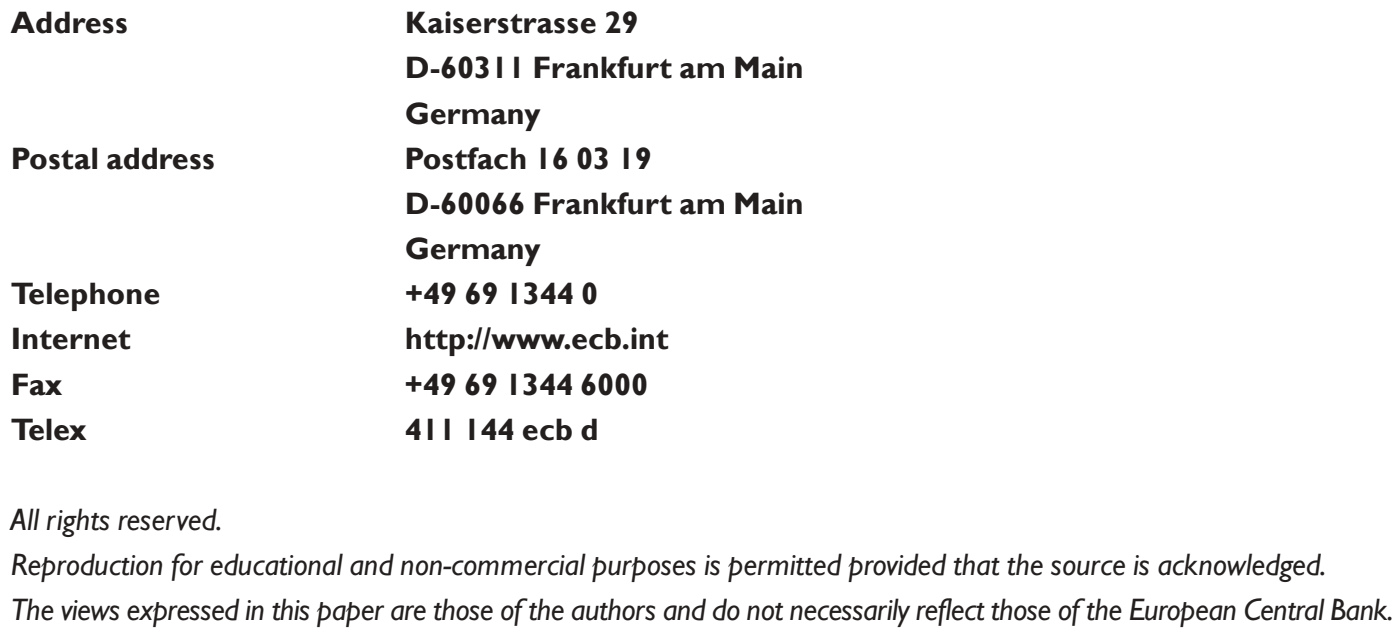

4 I I I 44 ecb d

Fax

All rights reserved.

Reproduction for educational and non-commercial purposes is permitted provided that the source is acknowledged.

The views expressed in this paper are those of the authors and do not necessarily reflect those of the European Central Bank.

ISSN $156 \mid-0810$ 


\section{Contents}

$\begin{array}{ll}\text { Abstract } & 4\end{array}$

Non-technical summary $\quad 5$

$\begin{array}{ll}\text { Introduction } & 7\end{array}$

I. Debt service in a Tax Competition Model of Fiscal Policy 9

The case of zero capital mobility 9

Allowing for perfect capital mobility 10

Allowing for taxation of immobile tax bases II

Summary: 6 hypotheses about the effects of debt service on the budget 12

2. Empirical Methodology $\quad 13$

The Basic Specification $\quad 13$

Allowing for Capital Mobility to affect Policy Responses to Debt Service in the
estimating equation

$\begin{array}{ll}\text { 3. The Data } & 17\end{array}$

$\begin{array}{ll}\text { Measures of Debt Service } & 17\end{array}$

Measures of Capital Mobility 18

Measures of Average Effective Tax Rates 19

4. The Estimation Results 20

The Basic Specification $\quad 20$

DSI versus DS2 21

Parameter estimates of other included variables 21

How does Debt Servicing affect Taxes and Expenditures $(\mathrm{HI}$ and $\mathrm{H} 2)$ ?

How does Capital Mobility change the Effect of Debt Servicing on the Budget
$(\mathrm{H} 3$ and $\mathrm{H} 4)$ ?

Does Capital Mobility shift the Tax Burden of Debt Service from Capital to Labor
and Consumption (H5 and H6)?

$\begin{array}{ll}\text { Conclusions } & 27\end{array}$

$\begin{array}{ll}\text { References } & 28\end{array}$

$\begin{array}{lll}\text { Appendices } & 31\end{array}$

$\begin{array}{ll}\text { Tables and Figures } & 40\end{array}$

European Central Bank Working Paper Series $\quad 54$

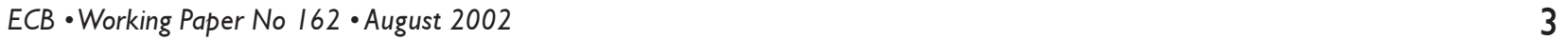




\begin{abstract}
The aim of this paper is two-fold: First, assuming public debts are pre-determined and in their steady state in EU countries, the paper investigates the effect of asymmetric debt service obligations on taxes, primary spending and the tax mix in EU countries. Second, it investigates how increased tax competition may change these effects. The impact of debt service on taxes, primary spending and the tax mix is derived in a simple model of tax competition, and the hypotheses derived from the model are tested empirically for a panel of EU countries. Crosscountry differences in public debts are found to lead to asymmetries in taxes and primary expenditures across EU countries, with high debt countries having lower expenditures and higher taxes than low debt countries. Capital mobility is found to increase these asymmetries, and trigger cross-country asymmetries in the tax mix of EU countries.
\end{abstract}

JEL classification: H6, H23, H73, H87, F02

Keywords: Public Debt, Public Finance, European Union, Asymmetric, Tax Competition 


\section{Non-Technical Summary}

The public debts of European Union countries are high and differ widely, and hence entail large and differing public debt servicing across member states. As an example, Italy spent an average of $17 \%$ of incoming tax revenues on interest payments on the public debt between 1970 to 1999 , while the corresponding percentage for Finland was 4\%. Assuming that the Maastricht criteria and the Stability Pact have lead to very limited reliance on deficit finance, the debt service associated with the large and differing public debt levels either must crowd out primary spending or increase tax revenues, or lead to a combination of the two. One can hence ask the question, has Italy a higher level of taxation or a lower level of primary spending than Finland, due to debt service, and all else being equal? More generally, does public debt service lead to higher taxes or lower spending in EU countries, assuming that public debts are in steady state and governments operate in a 'close to balance' environment? And in turn, do high debt countries spend less or tax more relative to low debt countries, such that public debt asymmetries imply spending and tax asymmetries across EU countries as well?

One can take the line of questioning one step further by observing that higher capital mobility and intensifying tax competition is suspected to add a downward pressure on tax rates in European Union countries, and to increase the level of distortions and deadweight loss associated with a given tax rate. If countries with high public debt have higher tax rates in order to service the debt, does this mean that high-debt countries increasingly suffer tax induced distortions relative to lowdebt countries due to increased tax competition? Or does tax competition mean that the effect of high debt service increasingly falls on the spending side of the budget rather than the tax side? Or does tax competition increasingly shift the burden of debt servicing from capital toward less mobile factors, such as labor?

Taking the levels of public debt as given in steady state, this paper investigates the effects of public debt asymmetries and tax competition on taxes and primary spending in the EU.

As the discussion above implies, two overall questions are addressed. First, may asymmetric levels of public debt across the European Union in themselves be a source of asymmetries in the size of the public sector, the overall tax level and the tax mix? Second, does tax competition increase or decrease the asymmetries in the size and in the tax structure of the state?

In order to formalize the questions, a simple model of tax competition augmented with a debt service term in the budget constraint is derived. The derivatives of the tax rate and government expenditures with respect to debt service are presented for the two extreme cases of zero capital mobility and perfect capital mobility. The model is subsequently augmented with taxation of an immobile tax base, to see whether capital mobility changes the relative impact of debt service on the taxation of the two tax bases. The model yields six testable hypotheses about the effect of debt service on the tax level, primary spending and the tax mix. These hypotheses are then tested empirically using panel regression techniques, for a panel of EU countries.

The results of the empirical investigation imply that public debt asymmetries are associated with asymmetries in the levels of taxes and primary expenditures across EU countries, with high debt countries having smaller public sectors and higher taxes than low debt countries. Moreover, it is 
found that capital mobility may increase these asymmetries while also triggering cross-country asymmetries in the tax mix of EU countries. Thus, when capital mobility increases, the tax increases made necessary by higher debt service obligations may fall increasingly on labor income and consumption rather than on capital. These findings have several implications. First, high-debt EU countries may be suffering from higher tax induced distortions to their economy compared to their lower-debt counterparts. Second, high debt levels in some EU countries, may, all else equal, have provided a mitigating effect on the tendency of the public sector (measured as primary expenditures) to grow in these countries, since debt servicing is found to partly crowd out primary expenditures. 


\section{Introduction}

The public sectors of European welfare states have reached unprecedented levels in history. Defining the size of the public sector in terms of the level of primary expenditures, the public sectors of EU countries have grown from an average of 33.2\% in 1970 to an average of $45.4 \%$ in 2000 , with this growth only halting in the $1990 \mathrm{~s}^{2}$. While public sector growth has taken place in virtually all European countries, its financing has differed widely, leaving the levels of public debt ranging from 46\% of GDP in Finland to 116\% of GDP in Belgium in 1999. Column 1 of table 1 shows the distribution of public debt to GDP ratios in EU member countries in 1999, and the accompanying debt service obligations.

The high and asymmetric levels of public debt across EU countries have been the trigger of a strain of literature aiming at empirically identifying the causes of these asymmetries. Roubini and Sachs (1989) opened this literature by searching for economic and political determinant of the budget deficit, which was followed by de Haan and Sturm (1994) and (1997), Hallerberg and von Hagen (1999), de Haan Moessen and Volkerink (1999), de Haan Sturm and Beekhuis (1999), and Kontopoulus and Perotti (1998) - the list is not exhaustive.

This paper looks at the facts from a different angle by considering the effects instead of the causes of public debt asymmetries. The public debt is taken as having reached a steady state level, and the effect of the associated asymmetric debt service obligations on other budget items is investigated. By assuming that changes in public finances induced by debt are neutral, in the sense that spending and taxation will change such that there is no change in the primary budget balance and hence in turn in the debt, the secondary effects of changes in the budget on the level of debt and sustainability are disregarded ${ }^{3}$. Hence, in contrast to the above-mentioned literature on the determination of public debt levels, this paper studies the causality from debt to primary spending and taxation assuming that debt is pre-determined - not the other way around.

Two overall questions are addressed. First, given the observation that the levels of public debt differ substantially across EU member countries, the question of how these asymmetries may lead to asymmetries in the fiscal policies of EU countries is posed. In other words, may asymmetric levels of public debt across the European Union in itself be a source of asymmetries in the size of the public sector, the overall tax level and the tax mix? Second, since tax competition in the European Union is under suspicion of putting pressure on taxes and, in turn, public spending, and of changing the tax mix, the question is raised as to whether recent trends of increasing tax competition in the European Union may change the way asymmetries in public debt lead to asymmetries in spending and taxation. Put differently, does tax competition increase or decrease the asymmetries in the size and in the tax structure of the state?

The mechanism through which the given level of public debt affects overall taxes, primary expenditures and the tax mix is the associated debt servicing item in the government budget

\footnotetext{
${ }^{2}$ Level of government defined as level of primary expenditures. Source: OECD Economic Outlook and own calculations. The average excludes the UK and Denmark, and only enters Ireland and Greece from when their series start, since they start in the 1970s (the data for UK and DK only starts in the 1980s).

${ }^{3}$ Except in as far as this becomes a source of endogeneity in the empirical analysis.
} 
constraint. Clearly, debt service obligations provide a substantial wedge in the budget of higherdebt countries, while this in not the case in lower-debt countries, all else equal. The last two columns of table 1 give an idea of the relative importance of debt service in the budgets of EU countries. Italy, Belgium and Greece take the lead by spending between $14 \%$ and $18 \%$ of tax revenues on interest for the public debt in 1999, compared to between $6 \%$ and $8 \%$ for France, Finland and the United Kingdom. The wedge in the budget stemming from debt service must affect either the level of tax revenues or the level of primary expenditures, assuming that there is a limitation to deficit financing. If debt servicing were to mainly result in higher taxes, and assuming that the excess burden of taxation is increasing in the tax level, this would imply that high debt results in a higher level of tax induced distortions to the economy ${ }^{4}$. If, alternatively, debt service is found to mainly result in lower primary spending, it would mean that debt can be considered a mitigating factor for the tendency of the public sector, as defined by primary expenditures, to grow.

Capital mobility and the potential for tax competition have increased dramatically in the European Union over the last decades. The mechanism for how increased tax competition may change the way public debt affects public finances is over the change in marginal costs of public funds associated with increasing tax competition. In short, tax competition raises the distortionary cost of a higher tax rate, and debt service could therefore be expected to increasingly result in lower primary spending instead of higher taxes. Moreover, it could also be expected that a given additional tax burden resulting from debt servicing would mainly be put on labor and consumption rather than on mobile capital.

To formalize these hypotheses, Section 1 presents a simple model of tax competition augmented with a debt service term in the budget constraint. The model is static, representing steady state, since sustainability issues are not the focus of the investigation. The derivatives of the tax rate and government expenditures with respect to debt service are presented for the two extreme cases of zero capital mobility and perfect capital mobility. The model is subsequently augmented with taxation of an immobile tax base, to see whether capital mobility changes the relative impact of debt service on the taxation of the two tax bases. The model yields six testable hypotheses about the effect of debt service on tax level, primary spending and the tax mix.

An empirical methodology for testing the six hypotheses is presented in Section 2. The simple theoretical model does not provide a fully-fledged structural framework from which an estimating equation can be derived. Instead, a framework for estimating tax and expenditure equations is derived by borrowing from the previously mentioned extensive empirical literature on determinants of the budget initiated by Roubini and Sachs (1989), as well as from the less developed empirical literature on the effects of capital mobility on taxes and expenditures.

Section 3 presents data for a panel of 13 EU countries, while the empirical results are presented in Section 4. The final section concludes.

\footnotetext{
${ }^{4}$ The excess burden of taxation is usually perceived, or assumed, to be increasing at an increasing rate in the level of taxation.
} 


\section{Debt service in a Tax Competition Model of Fiscal Policy}

In order to look at the effects of capital mobility on the effects of debt service on the budget, a standard tax competition model as in Zodrow and Mierzkowski (1989) is augmented with asymmetric levels of debt and debt service obligations. The complete model is presented in appendix. This section presents the main conclusions concerning the effects of debt service on taxes and spending in the two extreme cases of zero capital mobility and perfect capital mobility.

Zodrow and Mierzkowski assume an infinity of countries existing for only one period, and each country consists of a government and a representative citizen, who owns the production of a single (or composite) consumption good. The only input in production is capital, which enters with diminishing marginal returns ${ }^{5}$. Since the representative citizen owns the domestic production, he receives the profits after the employed capital is paid its marginal product. The representative citizen also owns a fixed amount of capital (his savings), which is invested in the production of the consumption good. Investments are made in the home production if capital is immobile, and savings may be invested domestically or abroad, wherever the after tax return to capital is highest, if capital is perfectly mobile. The government provides a public good, $g$, which may be transformed to a private consumption good at a one to one rate. The government also pays debt service on a predetermined amount of public debt, and levies a unit source tax on capital employed in domestic production in order to pay for the public good provision and the debt service. Assuming a balanced budget requirement, the budget constraint hence amounts to $t \cdot k=g+r D^{6}$. The government chooses the tax rate that maximizes a utility function, $u(g, x)$, which is increasing in expenditures on public goods (henceforth primary expenditures), $g$, and in the after-tax income of the representative citizen, $x$. The utility function can be thought of as the utility function of the representative citizen, the government being benevolent. Alternatively, the objective function can be thought of as the own utility function of a Leviathan government, who maximizes the size of the government (i.e. expenditures) as well as the probability of re-election, which could be assumed to be correlated with the after-tax income of the representative citizen. The equilibrium in terms of the tax level or size of government is the same in the two cases, the difference only consisting in whether the equilibrium tax rate is too high or too low from a socialoptimum point of view. Since the purpose of the modeling is to draw positive rather than normative conclusions about the impact of debt service on the budget variables for empirical testing, the view of government is irrelevant in the present context.

\section{The case of zero capital mobility}

Assume initially that capital mobility is zero (this in effect means that we look at one country isolated from the rest of the world since trade in capital is the only link between countries in this model). The representative citizen can only invest in the domestic production, irrespective of the domestic after-tax return to capital relative to that of other countries. In this case, the capital source tax does not have an effect on the investment decision and the marginal cost of public

\footnotetext{
${ }^{5}$ This can be thought of as a constant returns to scale production function with capital and labor as the two inputs, and where the representative citizen provides a fixed amount of labor.

${ }^{6} \mathrm{rD}$ can hence be any obligatory lump sum transfer into or out of the budget, which does not yield or substract utilty or create distortions by itself. Another example could be oil revenues.
} 
funds is unity (i.e. increasing overall tax revenues of the government by increasing the tax rate will result in a one to one decrease in private net income) ${ }^{7}$.

The first order condition for the governments problem is

$\frac{u_{g}(g, x)}{u_{x}(g, x)}=1$

Totally differentiating the first order condition with respect to debt service obligations, $r D$, and using the first order condition and the government budget constraint, the derivatives of the optimal tax rate and public spending with respect to debt service are derived:

$$
\begin{aligned}
& \frac{\partial t^{n}}{\partial r D}=\frac{\varepsilon^{n}{ }_{g}}{k \cdot\left(\varepsilon^{n}{ }_{g}-\varepsilon^{n}{ }_{x}\right)}>0 \\
& \frac{\partial g^{n}}{\partial r D}=\frac{\varepsilon^{n}{ }_{g}}{\left(\varepsilon^{n}{ }_{g}-\varepsilon^{n}{ }_{x}\right)}-1<0
\end{aligned}
$$

where $\varepsilon_{g}$ is the elasticity of the marginal utility of government spending with respect to the tax rate and $\varepsilon_{x}$ is the equivalent for the net income of the representative citizen ${ }^{8}$, and the superscript $n$ denotes no capital mobility equilibrium values.

This simple model of fiscal policy hence confirms the general intuition about how debt service payments are dealt with in the budget: one should expect to see a combination of a lower level of government spending and a higher level of taxes in countries with higher debt service obligations compared to countries with lower debt service obligations, all else equal. Splitting up the cost of debt service on taxes and primary expenditures minimizes the utility loss associated with debt service payments, and this is strictly due to the assumption of diminishing marginal utility of private net income as well as public spending. The division of adjustment between taxes and primary expenditures is determined by the parameters of the model. The greater (smaller) in absolute value the elasticity of the marginal utility of public goods provision (private net income) to the tax rate, the less primary expenditures will be adjusted and the more taxes will increase due to higher debt service.

\footnotetext{
Allowing for perfect capital mobility

Increased tax competition in theory limits the tax-raising powers of the government, and higher factor mobility may hence have an impact on the policy response to changes in debt service obligations - or changes in any other lump sum obligatory transfer for that matter. To see how capital mobility affects the above derivatives, the extreme case of perfect capital mobility is

${ }^{7}$ The definition of the marginal cost of public funds is the amount of private resources a one unit increase in tax revenues would cost, including both the direct transfer of tax from private or business to the government and the deadweight loss the increased tax imposes.

${ }^{8}$ The presence of $k$ in the numerator of the tax rate derivative, while missing in the derivative of primary expenditures, stems from the fact that $t$ is a tax rate, i.e. total taxes divided by the tax base, whereas $g$ is the total amount of public primary expenditures.
} 
evaluated. The representative household will invest its savings where the after-tax return to capital is highest, and capital flows will equalize the national after-tax returns to capital to the world after-tax rate of return. When the domestic tax rate is increased, the initial after tax return to capital will be lower and capital will therefore initially flow out of the country, until the marginal product of capital has increased with the same amount as the tax increase, leaving the after-tax rate of return unchanged. A change of the tax rate therefore has an impact on the investment decision of the representative citizen, or in other words, taxes are distortionary. The marginal cost of public funds is therefore greater than one, since a one unit increase in tax revenues results in a more than one unit fall in private net income due to the initial capital outflow and resulting lower production. The first order condition can now be written as:

$\frac{u_{g}(g, x)}{u_{x}(g, x)}=M C P F>1$

Under perfect capital mobility, the equilibrium marginal utility of public goods is higher than the marginal utility of private consumption since the relative cost of public good provision is higher. The government therefore sets a tax rate, which is lower than the optimal tax rate under zero capital mobility. The derivatives of the equilibrium tax rate and government spending with respect to debt service are derived in the same way as above:

$$
\begin{aligned}
& \frac{\partial t^{p}}{\partial r D}=\frac{\mathcal{E}^{p}}{\left(k+\frac{t^{p}}{f_{k k}}\right)\left(\varepsilon^{p}{ }_{g}-\mathcal{E}^{p}{ }_{x}-\varepsilon^{p}{ }_{m}\right)}>0 \\
& \frac{\partial g^{p}}{\partial r D}=\frac{\varepsilon^{p}{ }_{g}}{\mathcal{E}^{p}{ }_{g}-\varepsilon^{p}{ }_{x}-\varepsilon^{p}{ }_{m}}-1<0
\end{aligned}
$$

where the superscript $p$ denotes the perfect capital mobility equilibrium values and $\varepsilon_{m}$ is the elasticity of the marginal cost of public funds with respect to the tax rate under perfect capital mobility. The derivative of the tax rate with respect to debt service is smaller under perfect capital mobility, and the derivative of government spending is higher under perfect capital mobility (under certain conditions on the parameters of the model, the odd case of the derivative of the tax rate being larger under perfect capital mobility is allowed for by the model. See appendix). Hence, according to this simple capital tax competition model under certain conditions on the size of the parameters, paying debt service obligations by increasing the tax rate becomes increasingly distortionary as capital mobility and tax competition increase. According to the model, one budgetary effect of higher capital mobility may therefore be that high debt countries increasingly finance debt service obligations by reducing expenditures instead of levying higher taxes.

\section{Allowing for taxation of immobile tax bases}

A weakness of the above model is that it does not take into account that the government has other, less mobile, bases to tax. Extending the model to include taxation of an immobile tax base can be done very simply by letting the representative citizen provide some fixed amount of labor to the domestic production process and taxing this labor supply at the source. In this case, both 
tax rates are non-distortionary when capital is assumed internationally immobile and so the relative importance of the two is of no consequence to the net income level of the representative citizen, since both tax rates subtract income from her/him. Assuming that, ceteris paribus, the government prefers to set equal tax rates for simplicity or equity considerations, the effect of debt service on taxes and expenditures in this model will be the same as above, with the only difference that the change in the overall tax rate will be equally split between labor and capital taxation. When capital is allowed to flow freely across borders, however, capital taxation will be distortionary and hence more costly than the labor tax as a means of raising public funds. As a consequence, capital mobility will switch the entire tax burden onto labor taxation. Along the same line of reasoning, the part of public funds spent on paying debt service will switch from being paid by labor and capital equally to stemming entirely from labor taxation. Hence, the derivative of the capital income tax with respect to debt service should go from positive to zero while the derivative of the labor income tax rate should increase in order to take over the full financing of the debt service. More precisely, the derivatives of the two tax rates under zero capital mobility are:

$\frac{\partial t_{l}}{\partial r D}=\frac{\partial t_{k}}{\partial r D}=\frac{u_{g g}}{\left(u_{g g}+u_{g g}\right)(k+l)}$

while under perfect capital mobility they are

$\frac{\partial t_{l}}{\partial r D}=\frac{u_{g g}}{\left(u_{g g}+u_{g g}\right)(l)}, \quad \frac{\partial t_{k}}{\partial r D}=0$

The labor supply could be assumed to be elastic with respect to the tax rate by including disutility of labor in the utility function of the representative citizen. Allowing for an elastic labor supply would moderate the above result such that the capital mobility would not result in a complete switch to labor taxation (rather, the relative importance of the two taxes would be determined by the elasticities of the two tax bases through the Ramsey rule for optimal taxation) but in essence the result would be the same: The higher the capital mobility, the more of the tax burden is switched to the other factor, and the less of an increase in debt service would be paid by capital taxation relative to labor taxation.

Since consumption is also a potentially less mobile tax base, the above reasoning predicts that the higher the capital mobility is, the more the tax rate will increase on labor or consumption relative to the increase in capital taxation due to an increase in debt service.

\section{Summary: 6 hypotheses about the effects of debt service on the budget}

To sum up, the following six hypotheses are derived from the tax competition model of fiscal policy:

The higher the debt service obligations, the

H1: $\quad$ Higher the average over-all tax-rate 
H2: $\quad$ Lower the primary expenditure

The higher the capital mobility, the

H3: Smaller the effect of debt service on taxes

H4: $\quad$ Greater the negative effect of debt service on spending

H5. Greater the effect of debt service on labor income taxes relative to capital income taxes

H6. Greater the effect of debt service on consumption income taxes relative to capital income taxes

The six hypotheses are tested empirically in the next two sections.

\section{Empirical Methodology}

\section{The Basic Specification}

The theory presented in the previous section should be seen as providing predictions on the effects of debt service on the two sides of the budget. The tax competition model does not provide a fully-fledged structural framework from which an estimating equation can be derived. A framework for estimation is therefore inspired by two separate strands of empirical literature: Tax basic specification has been borrowed from the empirical literature on determinants of taxes, expenditures and the size of the budget deficit, while the inclusion of capital mobility has been inspired by the empirical literature on the effects of capital mobility on overall taxes and expenditures. Roubini and Sachs (1989a), belonging to the former strand of literature, propose an estimating equation for the yearly budget deficit including debt service as a separate item, and Kontopoulos and Perotti (1998), also belonging to the former strand of literature, use this basic specification - with slight alterations - for the two sides of the budget, taxes and expenditures as percentages of GDP. In line with Kontopolous and Perotti (1989), the following basic specification of the set of equations for estimation is put forward:

EQ.1. $\Delta B U D G E T_{i t}=\alpha+\beta \cdot \Delta\left[\begin{array}{l}B Y_{i, t-1} \\ R B_{i, t-1} \\ U B_{i, t} \\ G R_{i, t} \\ G R_{i, t-1} \\ I N F L_{i, t} \\ I N F L_{i, t-1} \\ M A A S\end{array}\right]+v_{i}+\varepsilon_{i t}$

The dependent variable, $B U D G E T$, is tax revenues in percent of GDP (TAX/GDP) when testing $\mathrm{H} 1$ and primary public expenditure in percent of GDP $(E X P / G D P)$ when testing $\mathrm{H} 2$. $B Y$ is the ratio of public debt to GDP, and is included with a lag. $R B$ is debt service obligations, which are also included with a lag to allow for policy to respond to changes. $U B$ is the unemployment rate. 
$G R$ is the real GDP growth rate and INFL is the percentage change in the consumer price index. $M A A S$ is a dummy for the "Maastricht years" and takes the value 1 from 1993 and onward. $v_{i}$ is a country specific error term (can be fixed or random) while $\varepsilon_{i t}$ is the country and time specific error term. See appendix for the precise definition of the variables used in the regressions.

The lagged gross debt to GDP ratio is included to control for efforts made to stabilize the budget. The tax ratio should therefore be a positive function of the lagged deficit while expenditures should be a negative function of the lagged deficit. The change in the unemployment rate is included to account for counter-cyclical fiscal policy and is therefore expected to affect the tax ratio negatively and expenditures positively. The real growth rate is expected to have a negative effect on expenditures to GDP ratio and the tax ratio in the short run, due to the cyclicality of the budget. Current growth should hence imply lower expenditures and revenues to GDP ${ }^{9}$. Current inflation may change the tax brackets in which income is taxed, since income brackets are nominal. Moreover, current inflation may be taken as a proxy for money growth and can hence be used to control for monetary financing of the budget. It is important to control for the monetary financing of the budget, since the use of seignorage has differed considerably across EU countries during the last 30 years. There is hence no clear expectation of the sign of the effect of current inflation on overall taxes, while the effect of inflation on total spending is expected to be positive. Lagged changes in real growth and inflation are included to control for the potential omitted variables bias due to these variables being correlated with the measure of debt service used as well as with the dependent variable (see the section on measures of debt service below). The dummy for the Maastricht years is entered to acknowledge that the nature of public finances changed during the run-up to the introduction of the single currency ${ }^{10}$.

If the real growth rate and debt service are not included in the above, the estimating equation is similar to the benchmark specification of Kontopoulos and Perotti (1998) for tax and expenditure ratios and for the primary deficit. And if $B U D G E T$ is set equal to the gross debt to GDP ratio, the equation is similar to the Roubini and Sachs (1989a) type of estimating equation ${ }^{11}$.

When testing for stationarity of the country specific data series in levels ${ }^{12}$, a unit root cannot be rejected for the majority of the country specific series for tax revenues or expenditures to GDP or unemployment, while a unit root is rejected for most of the countries when the first differences of taxes and expenditures in percent of GDP is tested. Although the length (or, rather, the lack thereof) of the country specific series implies that the strength of the unit root test is very low, the model is estimated in first differences to reduce problems of this potential non-stationarity. All included variables are hence first differenced in the benchmark regression, as indicated by the delta in EQ.1 above. Since growth and inflation hardly have unit roots, however, it could be

\footnotetext{
${ }^{9}$ It can also be argued that according to Wagner's Law, growth should lead to preferences for larger government and hence to higher taxes and expenditures in percent of GDP. But this is a longer-term argument as opposed to the above, and will not be taken into account here. Most empirical tests of Wagner's Law have rejected the hypothesis.

${ }^{10}$ To account more fully for the change in behavior of public financed due to the Maastricht process, interaction terms between the Maastricht dummy and the explanatory variables would be appropriate to include. This is done as a robustness check and results are shown in table 6 . Since the interaction term is not significant and does not change the relevant parameter estimates, this interaction term is left out for reasons of parsimony.

${ }^{11}$ With the only difference that inflation is added to the regression and proposed by Kontopoulos and Perotti 1998.

12 The results of ADF unit root tests can be downloaded from heiwww.unige.ch/ krogstr6/thesis/index.htm
} 
argued that these should be included in levels while first differencing the rest of the model. Estimating the model with growth and inflation in levels is carried out as a robustness check and commented on below.

The specification could alternatively be estimated entirely in levels including the lagged explanatory variable, but when the lagged dependent variable is included in a fixed effects panel regression, this introduces a bias due to the correlation of the lagged dependent with the fixed effects. The levels specification is also tested in the robustness analysis, but will not be emphasized due to the potential bias and unit roots. Including fixed effects (as will be shown to be appropriate in the next section) in the first difference specification allows for the country specific time trend in the levels. To facilitate comparison, a country specific time trend is therefore included when the levels specification is tested.

Another potential data problem is endogeneity. If the contemporaneous changes in debt service were used as regressor, and not the lag, there could be a case of endogeneity, since higher tax revenues (lower spending), would lead to a decrease of the public debt, in turn reducing debt service. Since all else is not necessarily equal, this correlation is not necessarily a problem, though. Now, the lag and not the contemporaneous value of changes in debt service is used as explanatory variable. Using the lag of debt service eliminates the problem of endogeneity described above, but creates another potential source of endogeneity: Changes in tax revenues or spending may potentially be correlated with the lagged changes (i.e. there may be persistence in the changes of taxes and spending), which in turn would be correlated with the lagged change in debt as described above. If changes in taxes or expenditures are auto-correlated and the first difference of taxes or expenditures are correlated with the contemporaneous change in debt service, then endogeneity may be a problem. If, however, the first differences of taxes or expenditures are not persistent, or if the first difference of taxes or expenditures is not correlated with the contemporaneous change in debt service, there should not be a problem of endogeneity, and when calculating the latter correlation, it in fact turns out to be minor ${ }^{13}$. Endogeneity is hence not considered to be a problem. Moreover, since the presence of endogeneity would bias the parameter estimates toward zero, the true parameter estimates would have the same sign but be larger in absolute value than the biased estimate. The presence of endogeneity would therefore still allow drawing qualitative conclusions, although the parameter estimates would only indicate a lower limit to what the true estimate would be.

\section{Allowing for Capital Mobility to affect Policy Responses to Debt Service in the estimating equation}

Increasing capital mobility affects the budget in two ways according to the tax competition model: it has a direct effect on the equilibrium tax rate and level of primary expenditures - the

\footnotetext{
${ }^{13}$ Levels of contemporaneous taxes and debt service are positively correlated with a correlation coefficient of 0.52 (using the first or second lead of debt service does not change the positive correlation to negative correlation). Levels of contemporaneous expenditures and debt are positively correlated with a correlation coefficient of 0.33 (using the first or second lead of debt service makes the positive correlation stronger). Changes in contemporaneous taxes and debt service are positively correlated with a correlation coefficient of 0.01 . Changes in the contemporaneous expenditures and debt are positively correlated with a correlation coefficient of 0.02 .
} 
traditional tax competition hypothesis - and it affects the reaction to changes in government debt service. Following the empirical specification of Garreth and Mitchell (2001), who study the effects of capital mobility of budget variables, an index of capital mobility is included in the estimating equation in addition to an interaction term between this capital mobility index and the measure of debt service ${ }^{14}$.

EQ.2. $\Delta B U D G E T_{i t}=\alpha+\beta \cdot \Delta\left[\begin{array}{l}B Y_{i, t-1} \\ R B_{i, t-1} \\ \operatorname{Icap}_{i, t-1} \cdot R B_{i, t-1} \\ \operatorname{Icap}_{i, t-1} \\ U B_{i, t} \\ G R_{i, t} \\ G R_{i, t-1} \\ I N F L_{i, t} \\ I N F L_{i, t-1} \\ M A A S\end{array}\right]+v_{i}+\varepsilon_{i t}$

Where Icap is an index of the degree of capital mobility. The next section contains a discussion of how to construct such an index. In addition to taxes and expenditures, the dependent variable $B U D G E T$ is the tax revenues and primary spending to GDP $(T A X / G D P$ and $E X P / G D P)$ when hypotheses three and four are tested, and the effective labor tax in percent of the effective capital income tax (henceforth $L A B C A P$ ) and the effective consumption tax in percent of the effective capital income tax (henceforth CONCAP) when testing hypotheses 5 and 6 . The rest of the included variables and subscripts are as outlined for EQ.1.

The construction of Icap, as explained in the next section, is such that zero is the maximum value it takes and zero and stands for perfect capital mobility, while the further below zero the value of Icap, the lower the degree of capital mobility, or in other words, when Icap increases it means that capital mobility increases. The parameter estimate for the pure debt service term in EQ 2 therefore measures the effect of debt service on the dependent variable under perfect capital mobility, while the interaction term measures the change in the effect of debt service when capital mobility increases (i.e. the change in the effect of debt service per unit of Icap). Support for hypotheses 3 and 4 would therefore require that the interaction term have the opposite sign of the debt service term for taxes and the same sign as the debt service term for expenditures. When hypotheses 5 and 6 are considered, only the interaction term is relevant and confirms the hypotheses if found to be positive. Finally, it should be mentioned that when the effective tax ratios are the dependent variable, the debt service term alone is expected to be positive in the tax

\footnotetext{
${ }^{14}$ Including the "raw" capital mobility index is important even though the direct effect is not the focus of this study, because it might be correlated with the interaction of capital mobility and debt service, and hence, excluding it might provide for an omitted variables bias of the parameter estimate of the interaction term.
} 
competition model allowing for labor taxation (since all taxes, including the ones induced by increasing debt servicing, will be put on the immobile factor).

\section{The Data}

The sample consists of yearly data for 13 EU member countries (EU15 less Luxembourg and Finland $)^{15}$ from 1970 to 1999 . The panel is unbalanced due to cross-country differences in data availability, and the average number of years of data per country is 24 . Most data are from the OECD economic outlook database, with some exceptions. Definitions and precise sources of the data are given in appendix.

Three types of data needed for the empirical analysis are not straightforward and deserve further comments: how to measure debt service, how to measure capital mobility and how to measure effective tax rates on capital, labor and consumption. Attention is devoted to these three categories of data below.

\section{Measures of Debt Service}

In a world similar to that of the tax competition model outlined above, with no tomorrow and hence no growth, the measure is the pure nominal interest payments on the public debt:

$$
D S 1 \equiv r_{t} \cdot b_{t}
$$

where $b$ is the debt to GDP and $r$ is the average nominal interest rate on government debt. But the government budget constraint is significantly affected by growth, and allowing for GDP growth makes the choice of how to measure debt service less clear. An alternative measure of debt service, which is similar to the measure proposed by Roubini and Sachs (1989a) and used in several studies after that, is given by the intertemporal budget constraint ${ }^{16}$ :

$$
D S 2 \equiv\left(r_{t}-\sigma_{t}\right) \cdot b_{t}
$$

Using the DS2 measure of debt service implicitly assumes that policy responds to the level of the primary balance, $t_{t}-g_{t}$, needed to keep the debt to GDP ratio unchanged. If growth increases, it gives the same leeway in the budget as if the interest rate on the public debt decreases, so a change in the interest rate on public debt only matters budget wise if the growth rate does not change in the same way as well. DS1, on the other hand, assumes that the policy response to changes in growth and the nominal interest payments are not the same, although the two effects provide the same air in the overall budget. A justification of this could be that pure interest

\footnotetext{
${ }^{15}$ Luxembourg is not included due to lack of available data. Finland is not included due to only a few years of available data as well as Finland statistically being an outlier in every regression for these few years.

${ }^{16}$ The intertemporal budget constraint is given by $t_{t}-g_{t}=\left(1+r_{t}\right) \cdot b_{t}-\left(1+\sigma_{t}\right) \cdot b_{t+1}$, where $t$ is the tax revenue to GDP ratio, $g$ is expenditures to GDP, and $\sigma$ is the nominal GDP growth rate. Making the assumption that $b_{t} \cong b_{t+1}$, we get $t_{t}-g_{t} \cong\left(r_{t}-\sigma_{t}\right) \cdot b_{t}$, implying that the measure of debt service which budget policy reacts to is interest payments net of the growth effect on the level of the debt Including monetary financing in the budget constraint would add a term depending on inflation and real growth, but it would not interact with the debt term and would hence not change the debt service measure coming out of this exercise.
} 
payments directly and visibly affect the budget and are predictable, while the effects of growth, all else equal, is to reduce the debt to GDP ratio. Moreover, the cash effect of pure interest payments in the budget has a different timing that the growth effect which may also affect the response of the policy maker.

If $D S 2$ is the correct measure and $\sigma_{t} \cdot b_{t}$ and $r_{t} \cdot b_{t}$ where not correlated, the parameter estimate of $D S 2$ and $D S 1$ should be the same. However, since $\sigma_{t} \cdot b_{t}$ and $r_{t} \cdot b_{t}$ are positively correlated $^{17}$, using $D S 1$ will be biased toward zero if $D S 2$ is the correct measure. As we will see in the next section, this does not turn out to be the case for the present panel.

If, on the other hand, $D S 1$ is the correct measure and $\sigma_{t} \cdot b_{t}$ does not have significant explanatory power, using DS2 in the regression will imply a higher standard error of the parameter estimate. The results of the analysis in the next section seem to confirm this scenario.

A regression including the interest part and the growth part separately can be used to test whether $D S 2$ is the right measure of debt service impacting on the budget, by testing whether the parameter estimate of the interest rate term is equal to minus the estimate of the growth term. The results of this test are shown and discussed in the next section.

Finally, it is important to clarify that using the lag of these two measures in the regression equation is what necessitates controlling for the lags of real growth and inflation in order to avoid omitted variables bias. This is because both measures - and DS2 in particular - are correlated with real growth and inflation, and because the lags of real growth and inflation both have significant explanatory power in the regressions (for example, the $D S 2$ changes sign when lagged growth is not included separately).

$D S 1$ and $D S 2$ are defined and calculated as implicit rates as given in appendix, and plotted for the panel countries in figures 1 to 8 . According to the DS1 measure, the countries most burdened by public debt of the sample are Belgium, Italy and Greece. When using the DS2 measure however, Greece is no longer among the top 3 debt burdened countries, and Italy only becomes one of the more debt-burdened countries later in the sample period. Moreover, the Netherlands, Denmark and Sweden are some of the more debt-burdened countries of the sample when the DS2 measure is used. This means that Greece and Italy have been able to partly outgrow or inflate away their public debt service over the period studied, without having to restrict their primary budget too much.

\section{Measures of Capital Mobility}

The degree of capital mobility is not directly observable or measurable, and there is therefore no obvious index of the degree of capital mobility of European Union countries. There is, however, a battery of suggested proxies, a non-exhaustive list of which is provided in appendix. A thorough overview of these measures and what they imply for capital mobility in EU countries is carried out in Krogstrup (2002), in which an empirical analysis of the effects of three of these measures

\footnotetext{
${ }^{17}$ With a correlation coefficient of 0.74 in the EU14 panel from 1973 to 1999.
} 
on taxes and expenditures in EU member countries is carried out. For reasons of data availability and because it provides a continuous measure, covered interest differentials is the only measure of the three which has credibly and accurately enough measures the degree of capital mobility. Moreover, it is the only measure providing intuitive and significant results. Covered interest parity differentials are hence used as measure of capital mobility in this study. Lemmen and Eijjfinger (1996) argue that if covered interest parity is not fulfilled between two countries, it must be because capital cannot flow freely to equalize this differential, and hence, capital cannot be perfectly mobile. The higher the divergence from covered interest parity, the greater the incentive to move capital and hence, the less capital can be mobile since it is not responding to this incentive. In line with Lemmen and Eijjfinger, the absolute value of the covered interest parity differential on 3 month interbank deposits (henceforth the CIP) are calculated for EU member country currencies vis-à-vis the German mark, using the formula

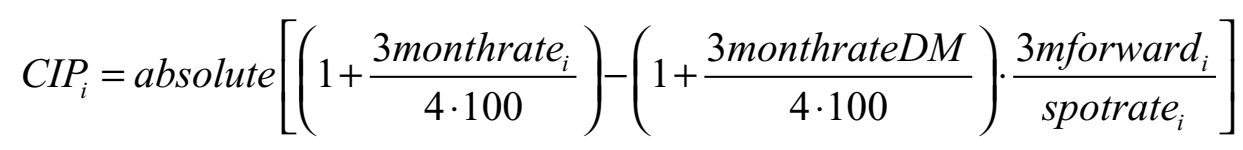

where 3monthrate is the 3 month interbank deposit interest rate for country i, 3mforward is the 3 month forward exchange rate and spot is the spot exchange rate vis-à-vis the Deutschmark. Data from Datastream and OECD Main Economic Indicators are used. Monthly averages were used since the longest series available for inter-bank deposit rates where provided by OECD Main Economic Indicators in monthly averages. Ideally, data observed on the same day of the month and even at the same time of the day would be preferable, since these are the prices observed by traders. End of month measures of inter-bank deposit rates and exchange rates are available with Datastream, but in substantially shorter series. Hence, the additional source of inaccuracy of using averages has been chosen over the loss of degrees of freedom associated with the use of end of month measures. Using monthly averages still provides an overall estimate of monthly averages of differentials from interest parity, and Lemmen and Eijffinger (1996) use monthly averages for the same reasons. The sample only extends until the end of 1998, after which national currencies no longer exists for most of the countries and hence cannot be used as tools to differentiate the CIPs between countries. Descriptive statistics for the calculated CIPs are shown in table 2 . Graphs of the CIPs over time per country are shown in figures 9-13 and show a very clear picture of increasing capital mobility over the entire period and strongest in the late 1980s - early 1990s in all EU countries. Due to the short sample for Greece, this country is excluded from the panel when the $C I P$ is included in the regressions. The value of the CIP for Germany is set to zero by assumption $^{18}$, and the robustness of results to the exclusion of Germany is tested.

\section{Measures of Average Effective Tax Rates}

The average effective tax rate (AETR) on labor, capital and consumption are not observable, and therefore have to be estimated from the tax statistics available. The literature proposes several

\footnotetext{
${ }^{18}$ Using Germany and not a third country (e.g. the US) as base country rests on the hypothesis that Germany had close to free capital movements for the entire period. This hypothesis is supported by the Quinn's 14-point index for Germany. Quinn's 14 point index only takes the values 13 or 14 for the entire period for Germany, implying that Germany had very few capital controls from 1970 to 1997 . This is contrary to all other OECD, which have values between 4 (Portugal) and 12.5 (US, Canada and Switzerland) in 1970, after which the score mostly increases for all OECD countries. Since Germany is the base country, the series is set to zero for Germany for the entire period.
} 
methods for how to calculate AETRs from available revenue and tax statistics ${ }^{19}$. The most influential paper on calculating AETRs is Mendoza, Razin and Tesar (1994), who base the calculations on the OECD revenue statistics. Carey and Thillinguirian (2000) provide updated and improved versions of the Mendoza et. al. (1994) effective tax rates, also based on the OECD revenue statistics ${ }^{20}$, and include average effective tax rates for EU15 countries less Luxembourg from 1980 to 1997. Carey and Thillinguirian's estimates have been used in this paper due to their sample length and coverage, and because of the improvements from previous estimates. Table 3 shows descriptive statistics for the average effective tax rates while descriptive statistics for the ratios of average effective labor and consumption tax rates to the effective capital tax rate are shown in table 4. Graph 14 shows the EU average effective labor and consumption tax rates in percent of the EU average effective capital tax rate between 1980 and 1999. Clearly both averages have been exhibiting an increasing trend over the last 20 years, supporting the frequent claim that increasing tax competition in the European Union has been switching the tax burden from capital to labor and consumption.

\section{4: The Estimation Results}

\section{The Basic Specification}

When testing the panel specification using the DS1 measure against the hypothesis that country regressions should not be pooled and are unrelated to each other, the pooling hypothesis is accepted. However, when the alternative hypothesis is that country equations should be estimated as seemingly unrelated regressions, thus allowing for cross-country correlation of the error terms, the hypothesis is rejected. When testing whether the restriction that the debt service term is equal across countries in an otherwise seemingly unrelated regression specification, the hypothesis is accepted when Spain and Portugal are not included in the tax regression, and when Denmark and Greece are not included in the expenditure regression. Due to the limited availability of countryspecific data, the panel specification is kept and the simultaneous exclusion of Spain and Portugal from the tax regression and Denmark and Greece from the expenditure regression respectively from the sample is tested in the robustness analysis.

Table 5 shows the results of the regressions of EQ.1 (henceforth called the basic specification) for the tax revenues to GDP ratio and primary expenditures to GDP ratio. In line with the empirical literature on determinants of the budget and the results of the Hausman test for fixed versus random effects (see table 5), the regressions are carried out with fixed effects ${ }^{21}$. The panel regressions for the tax ratio and the ratio of primary expenditures to GDP are estimated using FGLS, thus accounting for contemporaneous correlation as well as cross sectional heteroscedasticity. The two panel regressions are estimated in a system as two seemingly unrelated regressions, to increase efficiency in the presence of cross equation correlation of the disturbance terms.

\footnotetext{
${ }^{19}$ Mostly, a method is provided for categorizing different types of taxes into either the capital tax category, the labor tax category or the consumption tax category, as well as a way of defining the tax base to divide the categorized revenue with. These types of measures of AETRs are also called implicit tax rates.

${ }^{20}$ The data on average effective tax rates was kindly made available by David Carey.

${ }^{21}$ The estimated fixed effects are not shown but can be obtained from the author.
} 


\section{DS1 versus $D S 2$}

A regression including the interest part and the growth part separately can be used to test whether $D S 2$ is the measure of debt service inducing policy responses, by testing whether the parameter estimate of the interest rate term is equal to minus the estimate of the growth term. The results of this test are shown in the last row of table 5. The restriction is rejected, suggesting that $D S 2$ is not the measure of debt service to which budgetary policy reacts. Moreover, the parameter estimates for $D S 2$ are smaller in absolute value than the parameter estimates for $D S 1$, which is the opposite of what should be expected if $D S 2$ were the right measure. When testing the significance of $\sigma_{t} \cdot b_{t}$ in the regression including $D S 1$, the parameter estimate is not statistically different from zero in the expenditures regression, while slightly positive in the tax regression. The inclusion does not change the parameter value of $D S 1$ for either taxes or expenditures. The interaction of growth and debt is therefore left out entirely from the DS1 regression and the six hypotheses are tested only for DS1 in the following ${ }^{22}$.

\section{Parameter estimates of other included variables}

Parameter estimates of the regressions are for the most part in line with the previous literature on the determinants of fiscal policy. The lagged change in the debt to GDP ratio is insignificant in both regressions, implying either the lack of stabilizing reaction to changes in the debt or that the change in the debt is an imperfect measure of stabilization effort. The change in the unemployment ratio is significant and positively determining the change in primary expenditures $^{23}$, presumably capturing counter-cyclical expenditure policy. The change in unemployment is on the other hand insignificant in the tax regressions, possibly reflecting that counter-cyclical policy is not as strongly influencing the revenue side as the expenditure side of the budget. Both contemporaneous and lagged changes in real growth are highly significant and negative in both regressions, as is to be expected if nominal budgets are sticky ${ }^{24}$. The parameter estimates for inflation are significant and positive in both regressions except contemporaneous inflation in the tax regression, which is insignificant ${ }^{25}$. This positive effect of inflation on tax revenue is to be expected when tax brackets are nominal and sticky while the positive effect on expenditures may be capturing the positive effect of monetary financing on the budget, or the effect of indexation of certain expenditure items. The dummy for the Maastricht years is significant and does indeed indicate a more restrained expenditure policy after the ratification of the Maastricht treaty. Tax policy, however, does not seem to have been affected by the ratification of the Maastricht treaty.

\footnotetext{
${ }^{22}$ In order to check whether the statistical rejection of $D S 2$ term as the appropriate debt service measure is due to the increasing fiscal restraint after 1992, an interaction term between the Maastricht dummy and the debt service measure is included in the regressions. Table 6 shows the results. Clearly the added interaction term is not significant in any regression and the parameter estimates for the debt service terms do not change much. The Maastricht dummy interaction term is therefore left out and it is concluded that the DS1 measures is the empirically relevant measure of debt service which policy makers respond to.

${ }^{23}$ with a slightly lower parameter estimate, around 0.35, than that found in de Haan and Sturm (1993)

${ }^{24}$ The contemporaneous parameter estimates for the tax regressions are very similar to those found in Volkerink and de Haan (1999), and the ones of the expenditure regressions are in line with the findings of de Haan and Sturm (1993)

${ }^{25}$ This is in line with the findings of Perotti and Kontopoulos (1998) except for the estimated contemporaneous effect of inflation on expenditures, which is found to be negative and of a greater magnitude by Perotti and Kontopoulos (1998)
} 


\section{How Does Debt Servicing Affect Taxes and Expenditures (H1 and H2)?}

The regression results confirm hypotheses one and two, by showing that a one percentage point increase in the debt service to GDP ratio results in a 0.20 percentage point increase in the tax revenue to GDP ratio and a 0.37 percentage point fall in the primary expenditures to GDP ratio the following year. Since the sum of the two parameter estimates is below one, the change in debt service is not fully adjusted to in the budget the following year.

Considering the robustness of these results, the DW statistic is slightly high for the expenditures regression ${ }^{26}$. When the ratio of over 65 year old to the total population is included in the regression (see the first two columns of table 8) the DW statistic falls substantially, indicating a better fit when this variable is included. The inclusion does not have a substantial effect on the size of the parameter estimate for debt service though, so the basic specification is kept. Table 6 shows that the parameter estimates do not change substantially when an interaction term between the Maastricht dummy and debt service is included, and moreover, the interaction term is not significant, implying that the effect of debt service on the two sides of the budget did not change in response to the increasing fiscal restraint advocated by the Maastricht treaty. Table 7 shows that the parameter estimates of $D S 1$ are not driven by a single country, although the size vary somewhat according to which country is excluded. When Denmark and Greece are excluded from the expenditure regression, and when Spain and Portugal are excluded from the tax regression respectively, the parameter estimates become substantially larger and standard errors fall, confirming the findings of the tests for pooling of the data. Table 8 shows the tax and expenditure regressions including the participation ratio, the ratio of the population over 65 to the active population and the degree of openness of the economy, as well as when political variables - the contemporaneous and lagged value of a dummy for election years and the ideology of the government in power. The inclusion of these variables does not change the conclusions, but some of the parameter estimates are interesting in themselves. For example, the contemporary and lagged dummy for the election year show a clear election cycle in the tax regressions, with a fall in taxes before the election and an increase in taxes during or after the election ${ }^{27}$. The significant parameter estimates of debt service could be suspected to be capturing direct effects of changes in interest rates on the budget. To make sure this is not the case, table 9 shows results for the regression including the first difference of the long or short-term interest rate. Table 10 shows the results when the specifications is changed to include inflation and growth in levels instead of first differences, which may be a preferable specification since unit roots are not likely in the levels of these two variables. This change in specification does not change the conclusions ${ }^{28}$. Including

\footnotetext{
${ }^{26}$ The DW test statistics may or may not be significant. The significance cannot be evaluated using the usual DW tables when estimating a fixed effect panel regression. Bhargave et al. (1982) provide 5 percent significance points for the DW statistic in fixed effects panel regressions, but do not provide these for the panel dimensions of this analysis. Whether the size of the DW statistics are anything to worry about hence has to be judged by the naked eye.

${ }^{27}$ This is in line with the results of empirical political business cycle tests for 18 OECD countries in Galeotti and Salford (2001). But not all empirical investigations of election cycles in taxes and expenditures find supporting evidence. Alesina et al. (1997) only find the level of public debt to show clear election cycles while taxes and expenditures do not show election cycles, also for a panel of 18 OECD countries. Shi and Svensson (2001), on the other hand, find election cycles in both taxes and expenditures for a panel of 123 countries.

${ }^{28}$ Table 11 shows the results when the entire regression is estimated in levels including the lagged dependent variable and a linear country specific time trend to make the regression comparable to the one in first differences. The parameter estimate of $D S 1$ in the primary expenditures regression is now insignificant. However, the parameter
} 
only the first lag of the debt service variable and implicitly assuming that the time from a change in debt service is observed to a policy reaction is implemented is one year is rather arbitrary, and is adopted from the specifications of the previous literature on budgetary determinants ${ }^{29}$. Table 10 shows the regression results for the basic specification augmented with 2 more lags of the debt service variables ${ }^{30}$. The tax regression shows that the parameter estimate of the first lag is robust to the inclusion of the extra lags, while the extra lags are insignificant. The first lag of debt service in the expenditure regression does not change substantially either, but the additional lags of the DS1 measure are significantly negative. This indicates that expenditures' reaction to changes in debt service takes longer time, and may be greater than indicated by the regression results of the basic specification. Interestingly, the sum of the parameter estimates for the tree lags of DS1 in the expenditure regression can be statistically accepted to be equal to minus one, while the sum of the parameter estimates of the lags in the tax equation can be statistically accepted to equal to zero. Hence, the effect of debt service on taxes and expenditures may have a more complicated dynamic structure than that captured in the basic specification including one lag, since several additional lags are significant at least in the expenditures regression ${ }^{31}$.

To sum up for the results for the first two hypotheses, the data supports hypothesis one since a one percentage point increase in the debt service to GDP ratio leads to an average increase in the tax revenue to GDP ratio of 0.20 percentage points the year after, or between 0 to 0.35 percentage points depending on specification. The data also supports hypothesis two, and the size of the absolute impact on expenditures from changes in debt service is 0.37 , or between -0.20 and -1.00 depending on specification. The lower limit of 0 for taxes and -1.00 for expenditures come from taking a 3 year horizon and testing the restriction that changes in debt service are entirely absorbed by opposite changes in primary expenditures and taxes are not affected at all, which

estimate of DS1 is significantly negative in the expenditures regression in levels regression estimated to test hypotheses 3 and 4, and given the problems of including the lagged dependent variable in a fixed effects panel regression, and potential problems of non-stationarity, these results will not be emphasized.

NB: Including the lagged dependent in a fixed effects regression is a potential source of bias due to the correlation of the lagged dependent and the fixed effects. Kontopoulos and Perotti (1998), estimating their regression in levels as part of their robustness analysis, argue that since the sample of countries is conceptually fixed (in their case, OECD countries, in the present case, EU countries), and hence the asymptotics are based on T going to infinity, the estimator is consistent even though the lagged dependent variable is included. But since the sample length of the panel is far from going to infinity, although it is not short, it cannot be ruled out that the potential is substantial, and caution should hence be taken in interpreting the results of the regression in levels. Conclusions from the levels specification are hence not included directly in the robustness analysis, but the results are shown to allow comparisons.

${ }^{29}$ The time it takes from a change in debt service to hit taxes or expenditures can be conceptually divided into two components. First, the implementation lag, which is the time it takes from a statutory change in a tax rate or planned expenditure to translate into a change in tax revenues or actual expenditures. The second component is the time it takes from the change in debt service takes place till this is realized and initiative it taken to make room for it in the budget. One can only guess at how long this latter component might be in terms of time, and since forecasting may work rather well in this area, this part of the time lag might even be negative.

${ }^{30}$ The true lag length may be country specific and determining this true lag length would necessitate looking at the formal budgetary process of each individual country, which is beyond the scope of the this investigation.

Alternatively, one can test for how many lags to include statistically by applying a battery of tests for this purpose. A lag length of 2 is chosen without the backing of such tests since performing these tests does not give a clear answer as to how many lags to include, each of the tests suggesting a different number of lag length ranging from zero to 6 .

${ }^{31}$ A way of exploring the dynamic relationship in more detail would be to allow the short term dynamics to be country specific while restricting the long run relationship to be identical across countries using the pooled mean group estimator of dynamic heterogenous panels suggested by Pesaran et al (1997). 
cannot be rejected. This implies that debt service may be decreasing the size of the public sector rather than increases the tax level in the medium term. Exploring the dynamic relationship in more detail is left for future research ${ }^{32}$.

According to calculations based on the estimated effect of lagged debt service on overall taxes and primary expenditures of EU countries (see table 12), Greece was the country most affected by debt service obligations in 1999 , with an estimated $4.9 \%$ relative tax increase and $8.7 \%$ relative fall in primary expenditures due to debt service. In comparison, the United Kingdom was estimated to have had $1.5 \%$ higher taxes and $2.8 \%$ lower expenditures due to debt service during that year. Hence, cross country differences in the level of debt may be an important source of asymmetry in public finances and the size of the public sector across EU countries.

\section{How Does Capital Mobility Change the Effect of Debt Servicing on the Budget (H3 and H4)?}

Hypotheses 3 and 4, concerning the change of the effect of debt service on taxes and expenditures of increasing capital mobility, are tested by estimating EQ.2 for taxes and primary expenditures. The regressions are carried out with fixed effects, and the estimation procedure is the same as above. Greece has been excluded from the sample due to the few available observations of the $C I P^{33}$. Table 7 shows that excluding Greece does not change the regression of EQ.1 substantially, making it less likely to have an influence in EQ.2. Using the CIP substantially lowers the number of observations of the regressions. This shorter time dimension should be kept in mind when comparing the results of the parameter estimates of the regressions with and without the CIP. In general, the parameter estimates have slightly higher standard errors, which may be due both to the shorter sample, as well as to the slight increase in multicollinearity introduced by the inclusion of the two capital mobility terms.

Table 13 shows the results of the specification including $C I P$ and the interaction between $C I P$ and debt service, EQ.2. CIP is multiplied by minus one before being included in the regression, such that an increase in the CIP means an increase in capital mobility, to render interpretation of the parameter estimates more intuitive. The parameter estimates of the none-CIP terms stay more or less the same, the exception being the change in the unemployment rate, which becomes highly significant and negative in the tax regression when the capital mobility terms are included. It is interesting to notice that the direct effect of capital mobility on taxes is found to be negative, as expected, but the effect is not found to be significant. Moreover, capital mobility is found to have a significant positive impact on expenditures, which is the opposite of the general predictions of the tax competition literature ${ }^{34}$. Although these findings do not have direct implications for the hypotheses tested in the present paper, the fact that linked predictions of the model are not empirically supported implies that the model is not consistently empirically supported. This should be kept in mind when the results for hypotheses 3 and 4 are interpreted.

\footnotetext{
${ }^{32}$ See previous footnote.

${ }^{33}$ Greece could also be excluded on grounds that the country is an outlier in terms of the CIP. See figure 10 in appendix.

${ }^{34}$ This result would, on the other hand, support the hypothesis tested in Garreth and Mitchell (2001), stating that the higher is capital mobility, the higher is the need for social insurance against the induced increased volatility in economic activity, and the higher should public current spending be expected to be.
} 
Concerning the hypotheses three and four, the parameter estimates of the interaction terms show that the hypothesis that increased capital mobility should result in a smaller effect of debt servicing cost on taxes is not supported by the data. However, capital mobility is found to increases the downward pressure of debt service on primary expenditures. The effect of a one percentage point increase in the $D S 1$ under perfect capital mobility (i.e. when $C I P=0$ ) is to reduce primary expenditures ratio with 0.26 percentage points, and this impact is 0.09 percentage points smaller in absolute value for every percentage point decrease of the CIP below zero.

Concerning the robustness of these results, there are signs of negative autocorrelation in the expenditure regression and positive autocorrelation in the tax regression according to the DW statistic, but autocorrelation is not a problem when time and the interest rate are included as explanatory variables (see regression results in table 15). Both are significant in each regression, but their inclusion does not change the relevant parameter estimates considerably. The original specification is hence kept in spite of the autocorrelation. Table 15 shows that the parameter estimates of the interaction terms are robust to the inclusion of other explanatory variables, which could be suspected to be correlated with capital mobility. Table 14 shows that when Denmark or Spain is excluded from the panel, the standard error of the parameter estimates of the interaction term increase somewhat, but the parameter estimate for expenditures stays significant on the $10 \%$ level. Moreover, when Spain is dropped from the panel, the parameter estimate of the interaction term for taxes becomes significantly negative. Table 15 shows that the conclusions are robust to the inclusion of growth and inflation in levels instead of first differences.

To sum up, the effect of debt service on taxes is not found to change when capital mobility is higher, so hypothesis 3 is not supported by the data. There does, however, seem to be an effect of changes in the CIP on the impact of debt service on expenditures, lending support to hypothesis four. For each percentage point narrowing of the $C I P$, the negative effect of debt service on expenditures is estimated to be 0.09 percentage points higher, but the parameter estimate is somewhat dependent on changes in the sample. Caution should be shown in interpreting this finding, since capital mobility was not found to have any direct effect on taxes and a positive effect on expenditures.

\section{Does Capital Mobility Shift the Tax Burden of Debt Service from Capital to Labor and Consumption (H5 and $\mathrm{H6}$ )?}

EQ.2 is estimated for the effective labor and effective consumption to capital tax ratios to test hypothesis 5 and 6 concerning the effect of capital mobility on the relative importance of capital, labor and consumption taxes in the tax burden of debt servicing costs. As above, the regressions are carried out with fixed effects in a system using FGLS and Greece is excluded from the panel. Table 17 shows the results of the regressions.

The parameter estimates of unemployment and current and lagged growth are significantly positive while the current parameter estimate of inflation is negative and significant in both regressions. The lagged change in the debt level is positive and significant on the $10 \%$ level in explaining changes in the effective consumption to capital tax ratio while this is not significant 
for the effective labor to capital ratio. The Maastricht year dummy and lagged inflation are not significant in either regression. As discussed in section 2, the basic tax competition model without debt service predicts that capital mobility in itself puts a downward pressure on capital taxation relative to labor and consumption taxation, and the expected parameter estimate of the CIP terms in the regressions of the two effective tax ratios should therefore be positive. The opposite turns out to be the case, as in the CIP-regressions for taxes and expenditures above, in that the $C I P$ is found to have a negative effect on the consumption to capital effective tax ratio while it does not significantly affect the labor to capital effective tax ratio, and the same cautions in interpreting the results as above hence apply here.

Concerning the effect of debt service on the effective tax ratios and how this effect depends on the degree of capital mobility, remember that the parameter estimate for the pure debt service term gives the effect of debt service for a situation when capital mobility is perfect (i.e. when the covered interest differential is zero) while the parameter estimate for the interaction term between debt service and capital mobility gives the increase in the impact of debt service for each percentage point increase in the CIP away from zero. Debt servicing is found to be insignificant under perfect capital mobility in both tax ratio regressions, implying that a potential effect of debt servicing on taxes is distributed equally between the different tax bases when capital is perfectly mobile. At the same time, the significant and positive parameter estimate of the interaction term in both regressions mean that when capital mobility increases, the effect of debt service on the labor to capital tax ratio and on the consumption to capital tax ratio increases. Strictly speaking, this would imply that under imperfect capital mobility, debt service mostly results in capital income taxation, and when capital mobility increases, the effect of debt servicing will shift toward the less mobile factors, while under perfect capital mobility, the impact of debt service is the same for labor and capital income taxation. Hypothesis 5 is therefore, strictly speaking, supported by the data, as a one percentage point narrowing of the CIP results in a 0.43 percentage point increase in the effective labor to capital tax ratio per percentage point debt service. The corresponding number for the effective consumption to capital tax ratio is 0.32 percentage points. But the finding that the impact goes from a high tax burden on capital to a more equal split is not in line with the predictions of the tax competition model, that none of the tax burden of debt servicing will be put on capital when capital is perfectly mobile. One reason may be that there are many factors other than tax base mobility influencing the setting of tax rates.

Concerning robustness, both regressions show signs of positive autocorrelation, and the DW test statistic does not decrease when other explanatory variables are included (table 19), nor does it fall when using levels of the CIP (not shown). The relatively high value of the DW statistic may be a sign of misspecification or a result of poor data quality, but the basic specification is kept in lack of a better alternative. Table 18 shows that when Belgium is dropped from the panel, the standard error or the parameter estimate of the interaction term increases and leaves the parameter estimate significant only on the $10 \%$ level for the effective labor to capital tax ratio. Apart from this, the parameter estimates of the interaction terms are rather robust to changes in the countries included in the regression, to the inclusion of time and the interest rate as explanatory variables (table 19), and to including the growth and inflation terms in levels (table 19). 
To sum up for hypotheses 5 and 6, the data support these in a strict sense. Capital mobility is found to shift the debt service burden away from capital taxation and toward labor and consumption taxation. The impact on the effect of debt service on the effective labor to capital tax ratio is 0.43 percentage points per percentage point narrowing of the $C I P$, but varies between 0.33 and 0.69 depending on which countries are included in the sample. The estimated impact on the effect of debt service on the effective consumption to capital tax ratio is 0.32 percentage points per percentage point narrowing of the $C I P$, and this estimate varies between 0.22 and 0.36 depending on the countries included in the sample. However, the data do not support other predictions of the theoretical model, and thus, caution should be made in interpreting the above results.

Table 21 shows the average estimated effect on the labor and consumption to capital tax ratios of the change in capital mobility and the average debt service over the years 1985 to 1999 for EU countries, implied by the parameter estimates. The tax mix of Portugal was estimated to have been most affected by the increase in capital mobility combined with the existence of debt service obligations. As such, the effective labor (consumption) tax in percent of the effective capital tax was estimated to have increased by $6.3 \%$-points (4.6\%-points) between 1985 and 1999 due to increased capital mobility and debt service. In comparison, the numbers for the UK were $0.01 \%$ for both tax ratios.

\section{Conclusions}

According to a simple model of tax competition augmented with public debt and representing the steady state, high and differing levels of debt service across EU countries may lead to cross country differences in public finances, since debt service has to be financed from the overall budget. Six theoretical hypotheses about the effects of the associated debt service on overall taxes, primary expenditures and the tax mix, are derived and empirically tested for a panel of 13 EU countries (EU15 less Luxembourg and Finland).

The data supported the hypotheses that taxes are higher and primary spending is lower in highdebt EU countries compared to low-debt EU countries in the short run, all else equal. Thus, cross country differences in the level of debt were found to be an important source of asymmetry in public finances and the size of the public sector across EU countries. When a three year horizon was considered instead of one years horizon, the restriction that lagged changes in debt service lead to a one to one fall in primary expenditures while leaving the overall tax level unchanged could not be rejected.

The theoretical model also predicted that changing the degree of capital mobility has an effect on the impact of debt service on taxes and expenditures. Since tax induced distortions increase with the degree of capital mobility, debt service should increasingly results in lower expenditures of high-debt countries compared to low debt countries, and decreasingly results in higher taxes in high-debt countries compared to low-debt countries. This hypothesis was only partly supported by the data. The effect of debt service on taxes was found to be unchanged by the degree of capital mobility, while the data did indicate that the negative effect on primary expenditures of debt service is greater when capital mobility is higher. Hence, increasing capital mobility may result in 
increasing asymmetry among EU countries regarding the size of their public sectors. The partial rejection of the hypotheses derived from the theoretical model may be due to capital mobility and debt service affecting the budget balance rather than on the two sides of the budget. The theoretical model would not capture this due to the balanced budget assumption. The finding that expenditures react more to lagged changes in debt services when capital mobility is high and that expenditures change one to one with debt service in the medium term, may indicate that increasing capital mobility and tax competition leads to faster adjustment to budget balance rather than to a downward pressure on tax rates.

The theoretical model augmented with an immobile tax base predicted that debt service will increasingly be paid by taxes on the immobile factor rather than on capital when capital mobility increases. This hypothesis was supported by the data, although not very robustly so. Assuming that labor income and consumption are immobile tax bases, the effect of debt service on the effective labor tax as well as the effective consumption tax in percent of the effective capital tax increased with the degree of capital mobility. Increases in capital mobility were found to shift the tax burden of debt servicing from capital income and toward labor income and consumption, confirming a marginal tendency for capital mobility to shift the tax burden of debt servicing toward less mobile tax bases.

A caveat concerning the consistency of the estimated effects of capital mobility is in line here. The direct effects of capital mobility on taxes, expenditures and the tax mix, which where not in focus in this investigation but nevertheless were part of the implications of the theoretical model, were not supported by the data. This implies that the theoretical model was not supported entirely and this inconsistency of the empirical results should be kept in mind when the above conclusions about the effect of capital mobility are considered.

To sum up, public debt was found to lead to asymmetries in the levels of taxes and primary expenditures across EU countries, with high debt countries having smaller public sectors and higher taxes, at least in the short run, than low debt countries, all else equal. Moreover, the data did not reject the hypotheses that capital mobility may increase these asymmetries while also triggering cross-country asymmetries in the tax mix of EU countries. Thus, when capital mobility increases, the tax increases made necessary by higher debt-service obligations may fall increasingly on labor income and consumption rather than on capital. These finding have several implications. First, high-debt EU countries may be suffering from higher tax induced distortions to their economy compared to the lower-debt counterparts. Second, high debt levels in some EU countries, may, all else equal, have provided a mitigating effect on the tendency of the public sector (measured as primary expenditures) to grow in these countries, since debt servicing is found to mainly crowd out primary expenditures.

\section{References}

1. Alesina, A. and R. Perotti (1997): "Fiscal Adjustment in OECD Countries: Composition and Macroeconomic Effects". IMF Staff Papers; vol 44 no. 2; June 1997.

2. Alesina, A., Roubini, N and Cohen, GD (1997): "Political Cycles and the Macro Economy", Cambridge MIT Press 1997. 
3. Alesina, A., R. Perotti and J. Tavares (1998): "The Political Economy of Fiscal Adjustments" Brookings Papers on Economic Activity 1:1998.

4. Alesina, A. and R. Wacziarg (1998): “Openness, Country Size and Government”; Journal of Public Economics 69 (1998), p 305-321.

5. Barro, Robert J. (1979): "On the Determination of Public Debt", Journal of Political Economy, vol 87, no 5, pp 940-971

6. Bhargava, A., L. Franzini and W. Narendranathan (1982): " Serial Correlation and the Fixed Effects model.". Review of Economic Studies 1982, XLIX, 533-549.

7. Bohn, Henning (1998): "The Behavior of US Public Debt and Deficits", Mimeo, University of California at Santa Barbara.

8. Carey and Tchilinguirian (2000): “Average Effective Tax Rates on Capital, Labour and Consumption". OECD Economics Department Working Paper NO 258

9. Feldstein, M. and Horioka, C. (1980): "Domestic Savings and International Capital Flows". Economic Journal, 90, p. 314-329.

10. Galeotti, A. and Salford, G: (2001): "Electoral Cycles: Do They Really Fit the Data?", Tinbergen Institute Discussion Paper TI2001 076/1

11. Garrett, Geoffrey and Deborah Mitchell (2001): "Globalization, Government Spending and Taxation in the OECD", Forthcoming in European Journal of Political Research.

12. de Haan, Jacob, Wim Moessen and Bjoern Volkerink (1999): "Budgetary Procedures, Aspects and Changes: New Evidence for some European Countries" in Porteba and von Hagen (eds.): Fiscal Institutions and Fiscal Performance, University of Chicago Press, NBER 1999.

13. de Haan, J. and J. E. Sturm (1994): "Political and Institutional Determinants of Fiscal Policy in the European Community", Public Choice 80; p157-172; 1994

14. de Haan, J. and J. E. Sturm and g. Beekhuis (1999): "The weak Government Thesis: Some New Evidence" Public Choice 101; p163-176; 1999

15. Hallerberg, Mark and Jurgen von Hagen (1999): "Electoral Institutions, Cabinet Negociations, and the Budget Deficits in the European Union"; in Porteba and von Hagen (eds.): Fiscal Institutions and Fiscal Performance, University of Chicago Press, NBER 1999.

16. Hugounenq, Le Cacheux and Madies (1999): "Diversite des Fiscalite Europeenes et risques de concurrence fiscale", Revue de l'OFCE no 70, July 1999.

17. Kontopoulos, Yianos and Roberto Perotti (1998): "Fragmented Fiscal Policy". Mimeo, January 1998.

18. Krogstrup, Signe (2002): “Are Capital Taxes Racing to the Bottom in the EU?”, Unpublished manuscript, HEI, Geneva, 2002.

19. Lemmen, Jan 1998: "Integrating Financial Markets in the European Union". Edward Elgar Publishing Limited, 1998.

20. Lemmen, Jan and Sylvester Eijffinger (1996): "The Fundamental Determinants of Financial Integration in the European Union",Weltwirtschaftliches Archiv, Vol. 132, No. 3, 1996, pp. 432-456

21. Martinez-Mongay, Carlos, (2000): “ECFIN's Effective Tax Rates. Properties and Comparisons with other tax indicators". Economic Papers No 146, European Communities.

22. Martinez Mongay, C. and R. Fernandez Bayon (2000): "Effective taxation, spending and employment performance", European Commission (get the exact reference). 
23. Mendoza, Razin and Tesar (1994): "Effective Tax Rates in Macroeconomics Cross-country Estimates of Tax Rates on Factor Incomes and Consumption", Journal of Monetary Economics 34 (1994) p. 297-323.

24. Milesi-Ferretti, Gian Maria, Roberto Perotti and Massimo Rostagno (2001): "Electoral Systems and Public Spending". IMF Working Paper 01/22, February 2001.

25. Persson, Torsten and Guido Tabellini (2000): "Political Institutions and Policy Outcomes: What are the Stylized Facts? Unpublished manuscript, February 2001 version.

26. Pesaran, M. Hashem, Shin, Yongcheol and Smith, Ron P. (1999): "Pooled Mean Group Estimation of Dynamic Heterogeneous Panels", Journal of the American Statistical Association 94(446), June 1999. pages 621-34.

27. Popper, Helen (1993): "Long term covered interest parity: evidence from currency swaps". Journal of International Money and Finance, 12, p. 439-448

28. Rodrik, Dani (1996): "Why do more open economies have bigger governments?"; NBER Working Paper 5537, April 1996

29. Rodrik, Dani (1997): "Has Globalization Gone Too Far?" Institute for International Economics, Washington DC.

30. Roubini, Nouriel and Jeffrey Sachs (1989a): "Political and Economic Determinants of the Budget Deficit in the Industrial Democracies"; European Economic Review 33; p903-938; 1989

31. Roubini, Nouriel and Jeffrey Sachs (1989b): “Government Spending and Budget Deficits in the Industrial Countries"; Economic Policy 8, April 1989

32. Shi, M. and Svensson, J., (2000): "Political Business Cylcles in Developed and Developing Countries", World Bank Working Paper.

33. Swank, Duane (1998): “"Funding the Welfare State" Revisited: Globalization and Taxation in Advanced Market Economies". An update on "Funding the Welfare State: Globalization and Taxation of Business in Advanced Capitalist Economies", Political Studies 46 no4, September 1998, p 671-692.

34. Tanzi, Vito and Nigel Chalk. (2000): "Impact of Large Public Debt on Growth in the EU: A Discussion of Potential Channels". Unpublished Manuscript, IMF.

35. Volkerink and de Haan (2000a): "Tax Ratios: A Critical Survey", Mimeo, University of Groningen.

36. Volkerink and de Haan (2000b): "Fragmented Government Effects on Fiscal Policy: New Evidence", Mimeo, University of Groningen.

37. Volkerink and de Haan (1999): "Political and Institutional Determinants of the Tax Mix: An Empirical Investigation for OECD Countries", University of Groningen, Research Institute SOM Research Report 99E05.

38. Woldendorp, Jaap, Hans Keman and Ian Budge (2000): "Party government in 48 democracies (1945-1998)". December 2000, Kluwer Academic Pub.

39. Zodrow, G.R. and P. Mieszkowski (1986): "Pigou, Tiebout, Property Taxation, and the Underprovision of Local Public Goods". Journal of Urban Economics, 1986. 19(3): p. 356-70 


\section{Appendix}

\section{Data, Sources and Definitions}

The data used in the empirical analysis are described below and are from OECD Economic Outlook unless other sources are given in the table below. The overall sample size is 1972 to 1999. Some series start later or end earlier. The countries included in the sample are the EU15 less Luxembourg and Finland (due to poor availability of data for these countries). The construction of the index of ideology and the index of degree of capital mobility are described in more detail below.

\begin{tabular}{|c|c|}
\hline Variable & Definition and Sources \\
\hline $\begin{array}{l}\text { TAX/GD } \\
\mathrm{P}\end{array}$ & Total tax revenues in percent of GDP \\
\hline EXP/GDP & Primary expenditures in percent of GDP \\
\hline BY & $\begin{array}{l}\text { First difference of the debt to GDP ratio (Nominal gross debt and nominal gross } \\
\text { domestic product). }\end{array}$ \\
\hline DS1 & Gross interest payments on public debt in percent of GDP \\
\hline DS2 & $\begin{array}{l}\text { The average nominal interest on government debt less the nominal growth rate times } \\
\text { the debt to GDP ratio. The average interest on government debt is approximated by } \\
\text { the gross interest payment on public debt divided by the gross debt. }\end{array}$ \\
\hline UB & Unemployment rate \\
\hline GR & $\begin{array}{l}\text { The first difference of the real growth rate, calculated using data on nominal GDP } \\
\text { and the GDP deflator }\end{array}$ \\
\hline INFL & The yearly percentage change in the consumer price index \\
\hline MAAS & Dummy for the Maastricht years, taking the value 1 from 1993 onwards. \\
\hline PART & $\begin{array}{l}\text { The participation rate, constructed as labor force in percent of the population } \\
\text { between the age of } 15 \text { and } 65 \text {. (Data for Portugal are from the Ameco database. } \\
\text { Otherwise, the source is OECD Economic Outlook) }\end{array}$ \\
\hline OLD & $\begin{array}{l}\text { The population over the age of } 65 \text { in percent of the total population. (Data for } \\
\text { Portugal are from the Ameco database. Otherwise, the source is OECD Economic } \\
\text { Outlook) }\end{array}$ \\
\hline OPEN & Imports plus exports in percent of GDP. \\
\hline EYEAR & $\begin{array}{l}\text { Dummy taking the value } 1 \text { in years of parliamentary elections of the given country, } \\
\text { and zero otherwise. Source: Parties and Elections in Europe: http://www.parties-and- } \\
\text { elections.de/ }\end{array}$ \\
\hline IDEO & $\begin{array}{l}\text { Dummy for the ideology of the government in power. Construction as explained } \\
\text { below. Source: Woldendorp, Keman and Budge } 2000\end{array}$ \\
\hline LABCAP & $\begin{array}{l}\text { The average effective tax rate on labor in percent of the average effective capital } \\
\text { income tax. Source: Carey and Thilinguirian } 2000 \text {. }\end{array}$ \\
\hline CONCAP & $\begin{array}{l}\text { The average effective tax rate on consumption in percent of that of the average } \\
\text { effective capital income tax. Source: Carey and Thilinguirian } 2000 \text {. }\end{array}$ \\
\hline CIP & $\begin{array}{l}\text { Calculated as laid out in section } 3 \text {. The data is from Datastream and OECD Main } \\
\text { Economic Indicators }\end{array}$ \\
\hline
\end{tabular}




\section{Construction of an index of ideology}

In line with the empirical literature on the effects of ideology on fiscal policy ${ }^{35}$, data provided by Woldendorp, Keman and Budge 2000 on ideology of the government in power is used. They provide a classification of the ideology of government by breaking it down to five cases:

1. Right wing parties dominate both government and parliament.

2. Right wing or center parties make up between $33.3 \%$ and $66.6 \%$ of government

3. Center parties make up more than $50 \%$ of government

4. Left wing or center parties make up between $33.3 \%$ and $66.6 \%$ of government

5. Left wing parties dominate government

Woldendorp et al 2000 describes how the distinction has been made between right wing, center and left wing parties. On the basis of this data series, two dummies have been constructed. The right wing dummy (RIGHT) takes the value one in case 1 and 2 while the left wing dummy (LEFT) takes the value one in case 4 and 5. These dummies correspond to the dummies right and left constructed in Volkerink and de Haan 1999.

Covered Interest Parity Differentials (CIP), calculated as laid out in the above section..

\section{Measures of capital mobility}

\section{Introduction}

Just as there is no perfect, but several imperfect, measures of the tax burden on capital, there is no straightforward measure of the degree of capital mobility, but there is a battery of suggested proxies. Approaches to constructing empirical measures of capital mobility can be split into 4 different categories: The legal/formal approach; the volume approach; the price approach; and the macro approach. Each type of measure, what it has to say about the degree of capital mobility in the European Union over the past few decades and whether the measure is appropriate to use in the panel regression analysis is discussed in this section.

\section{The legal/formal approach}

The degree to which capital flows freely across national borders is influenced, if not entirely determined by, the legal framework governing financial transactions between residents and nonresidents of a country. National financial regulation can therefore be coded into an index of the restrictions to the free movement of capital mobility. The simplest way of creating an index of capital mobility based on the legal/formal framework is to create a dummy taking the value one if some type of restriction of cross border financial transactions is in state in the respective country, and zero otherwise. Alesina et al (1994), among other studies ${ }^{36}$, construct four dummies on the basis of information from the Annual Report on Exchange Restrictions of the IMF, each dummy taking the value of one if there are restrictions in one of the four following areas of financial cross border transactions: the existence of multiple exchange rates, restrictions on current account transactions, restrictions on capital account transactions and requirements of surrender of export

\footnotetext{
${ }^{35}$ See for example Volkerink and de Haan (1999) and (2000b)

${ }^{36}$ A non-exhaustive list of studies using discrete legal measure of capital mobility is Grilli and Milesi-Ferretti (1995), Rose (1994), Epstein and Schor (1992), and Garrett (1995).
} 
proceeds. The dummies can both be used separately or a weighted average of the four dummies could be used as a capital mobility index.

Quinn (1997) proposes a more sophisticated measure of capital mobility based on the legal/formal framework governing international capital transactions, also based on information on financial regulation from the above mentioned IMF publication. Quinn's 14 point index is constructed using a scoring system to translate restrictions on not only outward but also inward capital account transactions, outward and inward current account transactions, and finally, the existence of agreements limiting the future use of capital controls, into a quantitative measure ranging from 0 (financially closed) to 14 (financially fully open). Quinn proposes using the first difference of the 14-point index as a measure of financial liberalization.

Perhaps the most important drawback of the legal/formal approach to measuring capital mobility is its discrete nature, since the sheer presence of restrictions does not necessarily convey any information about the magnitude of the actual impact of the restriction on capital flows. Nonlegal restrictions of cross border capital flows, such as transaction costs or institutional barriers, may also have significant influence the degree of capital mobility ${ }^{37}$.

\section{The volume approach:}

Another measure of the degree of capital mobility widely used in the literature is the volume of gross cross border stocks or flows of either portfolio capital, foreign direct investment flows or both, and rests on the assumption that increases in capital mobility, and rests on the assumption that increases in the mobility of capital results in increasing flows of cross border investment.

Both stocks and flows of cross border investment have been used in the literature as measures of capital mobility $^{38}$. Which of the two measures is the conceptually more consistent one to use as a proxy for capital mobility depends on whether a certain degree of capital mobility corresponds to an equilibrium level of gross stock or gross flow of foreign investment. Arguably, if two countries with different returns to investment and zero capital mobility between them open up to capital flows, capital would flow until the returns to capital were equalized, after which there would be no more incentive for capital flows. Hence, a certain stock of foreign investment would correspond to a certain degree of capital mobility in equilibrium, which implies that stocks would be the more correct measure of the degree of capital mobility. New estimates of stocks of FDI and portfolio equity investment positions carried out by Lane and Milesi-Ferretti (2001)

There are several drawbacks in using this approach to measuring capital mobility. As mentioned above, the volume approach to measuring capital mobility rests on the assumption that increases in the mobility of capital results in actual cross border capital flows. This assumption is a weak point, as investment decisions do not necessarily respond to increases in the mobility of capital if there are no price incentives to respond to, and vise versa, capital may flow across borders if price differentials become high enough, even when the cost of the cross border transaction has not

\footnotetext{
${ }^{37}$ See Grilli and Milesi-Ferretti (1995) for a more thorough discussion of drawbacks of the simple dummy approach.

${ }^{38}$ Obstfeld and Taylor (2001) look at cross border stocks of FDI and portfolio investment as an indicator of capital mobility, while Garreth and Mitchell (2001) and Swank (1998) use FDI and portfolio capital flows.
} 
changed. Similarly, it is possible that increases in capital mobility result in changes in asset prices rather than offsetting capital flows.

\section{The price approach}

Covered Interest Parity differentials (CIP)

As mentioned in the paragraph on the dummy approach to measuring capital mobility, using dummies for the existence of capital restrictions does not sufficiently describe the degree of capital mobility. Moreover, increased capital mobility may tend to equalize prizes (i.e. interest rates) rather than producing actual capital flows, as mentioned in the paragraph on the volume approach. A way of getting around both critiques is to look at the price differential directly. Based on the assumption that the higher the price differential net of currency risk between two identical assets of different nationality, the higher restrictions, formal or informal, to capital mobility must be since price-offsetting flows have not been triggered to take advantage of the arbitrage opportunity. In other words, in a regime of perfect capital mobility, some sort of interest parity condition should hold while the lower the degrees of capital mobility is, the higher a differential from interest parity should be possible without triggering arbitrage activity. The covered interest parity differential is commonly used for measuring interest parity differentials due to its implementalibity and availability of data.

Covered Interest Parity differentials:

Covered interest parity (henceforth CIP) is based on the notion that the return on two identical assets denominated in different currencies should be the same when currency risk is hedged in the forward market, default risk and liquidity characteristics of the two assets are the same and capital is perfectly mobile. The differential from CIP can hence be written:

$\rho_{t, \delta}=1+r_{t, \delta}-\left(1+r^{*}{ }_{t, \delta}\right) \cdot \frac{F_{t, \delta}}{S_{t}}$

where $\rho$ is the covered interest parity differential at time $t$ with respect to an asset of a maturity of $\delta, r$ is yield of the domestic interest rate, $r^{*}$ is the yield of the foreign asset interest, $F$ is the forward exchange rate at time $t$ for time $t+\delta$ and $S$ is the spot exchange rate at time $t$, expressed in domestic currency per foreign currency. The differential can consist of differential default risk of the two assets, differential liquidity premiums of the two assets, differential transaction costs or capital controls. It is therefore important to choose assets, which are as similar as possible with respect to default risk and liquidity in order to minimize the measurement error of the two latter components of the differential which amount to capital mobility.

Ideally, interest and exchange rate data observed on the same time of day and the same day should be used to calculate the differential, but collecting such data for a panel of EU countries limits the sample size substantially compared to using monthly averages of the relevant variables. Since the availability of data on monthly averages is better and following Lemmen (1996), monthly averages of data on 3-month inter-bank deposit interest rates, 3-month forward exchange rates and spot rates from Datastream and OECD Main Economic Indicators are used to calculate CIPs 
for 14 European Union countries. In the defense of using monthly averages, note that if interest parity holds for data sampled at the same time in the month, then it should also hold for monthly averages. On the other hand, a value close to zero of the CIP calculated using monthly averages does not necessarily imply that interest parity holds for data collected at the same time in the month, implying that using monthly averages may tend to understate the differentials from interest parity. This potential for understatement should be kept in mind when analyzing the estimates.

An alternative to the short-term covered interest differential would be to calculate covered interest differentials for longer-term assets, as a measure of longer-term capital mobility. However, to the knowledge of the author, no convincing methodology has as of yet been devised for calculating such interest differentials ${ }^{39}$.

\section{Cross border asset price correlations}

Another measure belonging to the category of price measures of capital mobility is cross border equity price correlations. It can be argued that when the mobility of capital is higher, capital should respond more easily to market specific changes in risk and return to equity by seeking other countries with better risk return profiles, all else equal. Hence, equity prices should co-vary across countries. However, using cross-country equity price correlations as a measure of cross border capital mobility has many potential pitfalls. Among these are that co-variation may be due to common shocks rather than capital flows responding to changes in cross border differences in price or uncertainty driven by country specific events ${ }^{40}$. Similar problems are present for crosscountry bond price correlations as a measure of capital mobility.

\section{The macro approach}

The macro approach to measuring the degree of capital mobility includes two measures: withincountry savings-investment correlations and cross-country consumption correlations. The former is used as a measure of capital mobility because the less savings and investment are correlated within a country, the more access that country must have to international financial markets to smooth investment, and the higher is the degree of capital mobility. Feldstein and Horioka (1980), and more recently Hussein (1998) and Lehner (1998), among others used the approach. The latter measure is used since the higher degree of correlation of consumption across countries, the more access consumers of each country must have to international financial markets to smooth consumption and the higher is the degree of capital mobility. Important critiques of the two measures of capital mobility have been put forth. One such critique is that savings and investment as well s cross country consumption can be correlated due to common shocks rather than a lack of financial integration - the same problem with the use of cross country asset price

\footnotetext{
${ }^{39}$ Popper (1993) provides a methodology for calculating long term interest differentials, but her approach has conceptual problems which make her methodology unconvincing. Using currency swap rates as well as interest swap rates, she converts the yield of the foreign currency asset into a domestic currency yield and compares, but she does not take into account that the same yield may be derived from different coupon/principal profiles of the foreign currency bond, in turn implying differences in risk profiles, which would make the bonds incomprable.

${ }^{40}$ Obstfeld and Taylor (2001) look at equity price correlations to evaluate changes in the degree of international capital mobility over the last century. They show that changes in correlations do not correspond closely with the consensus u-shape perception of the degree of capital mobility over the last century. Rather, correlations are likely to stem from common shocks (which was clearly the case in the 1920s and 1930s) rather than globalization per se.
} 
correlations as a measure of financial integration ${ }^{41}$. Moreover, the measures are usually calculated as a single correlation coefficient for a country or for a group of countries, since yearly data is used. Thus, these measures do not produce a time and country dependent index of capital mobility, which would be needed in order to use it in a panel regression.

\section{Summary}

Four approaches to constructing a measure of the degree of capital mobility have been presented. First, the legal/formal approach, which looks at whether restrictions to the cross border movement of capital are formally in state. Second, the volume approach which looks at the volume of cross border capital transactions as a measure of the degree of capital mobility. Third, the price approach, based on the notion that capital will move to equate prices across borders if it is free to do so, and hence uses cross border asset price disparities as an indicator or the degree of capital mobility. And finally, the macro approach based on the assumption that free access to international capital markets should result in consumption smoothing and the detachment of investment and savings within countries and view the lack of the presence of these as evidence of lack of capital mobility.

\section{A simple model of tax competition with asymmetric public debt levels}

Production:

$y=f(k), \quad f_{k}>0, \quad f_{k k}<0, \quad f_{k k k}=0$

where $\mathrm{k}$ is the amount of capital invested in domestic production.

The representative citizen owns the production and a certain amount of capital which is invested either domestically or abroad depending on whether capital is mobile or not, so the private budget constraint is:

$x=f(k)-f_{k} \cdot k+r \cdot \bar{k}$

where $\bar{k}=$ the representative citizen's holdings of capital and $\mathrm{r}$ is the after-tax return to capital. Since there is no tomorrow, the representative citizen will spend all her/his current income on private consumption, $\mathrm{x}$, hence the equality sign.

The government levies a source unit tax, $t$, on capital employed in domestic production and uses the tax revenues to pay debt service and to provide a public good, $g$, which is produced one to one from the composite consumption good. The government budget constraint is hence:

$t \cdot k=g+r D$

The government chooses the tax rate that maximizes the objective function:

${ }^{41}$ See Lemmen (1998) for a discussion of problems with the two macro approaches to measuring capital mobility. 
$u(g, x), \quad u_{g}, u_{x}>0, \quad u_{g g}, u_{x x}<0, \quad u_{g x}, u_{x g}=0$

under the budget constraint.

\section{The case of zero capital mobility}

Under zero capital mobility, the representative citizen can only invest her/his capital in the domestic production. Capital owned by the representative citizen and capital employed domestically are therefore the same and the private budget constraint reduces to:

$x=f(k)-t \cdot \bar{k}$

Hence, domestic course taxation of capital is non-distortionary and the first order condition for the government's problem becomes:

$\frac{u_{g}^{\prime}(g, x)}{u_{x}^{\prime}(g, x)}=1$

Totally differentiating the first order condition with respect to debt service yields the total derivatives of the equilibrium tax rate and government spending:

$$
\begin{aligned}
\frac{\partial t^{*}}{\partial r D} & =\frac{\varepsilon^{n c m}{ }_{u_{g}}}{k \cdot\left(\varepsilon^{n c m}{ }_{u_{g}}+\varepsilon^{n c m}{ }_{u_{x}}\right)}>0 \\
\frac{\partial g^{*}}{\partial r D} & =\frac{\varepsilon^{n c m}{ }_{u_{g}}}{\left(\varepsilon^{n c m}{ }_{{ }_{u_{g}}}+\varepsilon^{n c m}{ }_{u_{x}}\right)}-1<0
\end{aligned}
$$

where

$$
\begin{aligned}
& \varepsilon_{u_{x}}^{n c m}=\frac{\partial u_{x}}{\partial t} \cdot \frac{t}{u_{x}}=-\frac{u_{x x}}{u_{x}} \cdot k \cdot t>0 \\
& \varepsilon_{{ }_{u_{g}}^{n c m}}^{n}=-\frac{\partial u_{g}}{\partial t} \cdot \frac{t}{u_{g}}=-\frac{u_{g g}}{u_{g}} \cdot k \cdot t>0
\end{aligned}
$$

\section{Allowing for perfect capital mobility}

When capital is perfectly mobile, the representative citizen may move her/his capital abroad to attain the world after-tax return to capital if the after-tax return to capital is lower domestically. The financial market equilibrium condition therefore becomes:

$f_{k}-t=r$

where $\mathrm{r}$ is the world after-tax return to capital, considered fixed by the actors of the model, and $f_{k^{-}}$ $t$ is the domestic after-tax return to capital. 
Since an increase in the domestic tax rate will now trigger a capital outflow until the marginal productivity of capital has increased correspondingly, the source tax on capital is distortionary and a tax increase will not just increase taxation of the representative citizen one to one, it will also reduce production, and hence, the marginal cost of increasing public spending in terms of loss of private net income it larger than one. The first order condition for the solution of the government's problem is in this case:

$\frac{u_{g}^{\prime}(g, x)}{u_{x}^{\prime}(g, x)}=M C P F>1$

Totally differentiating the first order condition with respect to debt service yields the total derivatives of the equilibrium tax rate and government spending under perfect capital mobility:

$\frac{\partial t^{*}}{\partial r D}=\frac{\varepsilon^{p c m} u_{g}}{\left(k+\frac{t}{f_{k k}}\right) \cdot\left(\varepsilon^{p c m}{ }_{u_{g}}+\varepsilon^{p c m}{ }_{u_{x}}+\varepsilon_{m c p f}\right)}>0$

$\frac{\partial g^{*}}{\partial r D}=\frac{\varepsilon^{p c m}{ }_{u_{g}}}{\varepsilon^{p c m}{ }_{u_{g}}+\varepsilon^{p c m}{ }_{u_{x}}+\varepsilon_{m c p f}}-1<0$

where

$$
\begin{aligned}
& \varepsilon^{p c m}{ }_{u_{x}}=\frac{\partial u_{x}}{\partial t} \cdot \frac{t}{u_{x}}=-\frac{u_{x x}}{u_{x}} \cdot k \cdot t>0 \\
& \varepsilon^{p c m}{ }_{u_{g}}=-\frac{\partial u_{g}}{\partial t} \cdot \frac{t}{u_{g}}=-\frac{u_{g g}}{u_{g}} \cdot\left(k+\frac{t}{f_{k k}}\right) \cdot t>0 \\
& \varepsilon^{p c m}{ }_{m c p f}=\frac{\partial m c p f}{\partial t} \cdot \frac{t}{m c p f}=\frac{t}{k \cdot f_{k k}}-\frac{t}{k+\frac{t}{f_{k k}}} \cdot \frac{2}{f_{k k}}>0
\end{aligned}
$$

In order to compare the size of the two derivatives, evaluate these in the point of symmetric equilibrium with no debt, such that capital is allocated equally between all countries and the capital account is neutral (i.e. $k=\bar{k}$ in both regimes in equilibrium) when the increase in debt service occurs. Keep in mind that the tax rate and public spending are lower under perfect than under zero capital mobility according to the first order conditions, while private net income under perfect capital mobility is higher than under no capital mobility in symmetric equilibrium. Assume further that the second derivatives of the utility function are constant in their respective arguments (third derivatives zero), such that they are constant across the two regimes. In this case, the condition for the derivative of the tax rate with respect to debt service to be greater under zero capital mobility is: 
$u_{g g}>m c p f \cdot u_{x x}+(1-m c p f) \cdot \frac{u_{g}^{p}}{t^{p} \cdot k}$

which shows that as long as the second derivative of the utility function with respect to public spending is not substantially larger than the second derivative with respect to private net income in absolute value, the condition is fulfilled (For a discussion of the intuition behind this condition, a paper going more into depth with this condition can be obtained from the author).

As a numerical example, the case of quasi linear utility clearly only allows for the derivative to be larger in no capital mobility case.

\section{Allowing for taxation of immobile tax bases}

The derivative of the two tax rates under zero capital mobility is:

$\frac{\partial t_{l}}{\partial r D}=\frac{\partial t_{k}}{\partial r D}=\frac{u_{g g}}{\left(u_{g g}+u_{g g}\right)(k+l)}$

while under perfect capital mobility they are

$$
\frac{\partial t_{l}}{\partial r D}=\frac{u_{g g}}{\left(u_{g g}+u_{g g}\right)(l)}, \quad \frac{\partial t_{k}}{\partial r D}=0
$$




\section{Tables}

Table 1. Public Debt and the Relative Importance of Debt Service for the Budget

\begin{tabular}{|c|c|c|c|c|}
\hline & $\begin{array}{c}\text { Gross Public Debt } \\
\text { in percent of } \\
\text { GDP, } 1999\end{array}$ & $\begin{array}{c}\text { Gross interest } \\
\text { payments on } \\
\text { public debt in } \\
\text { percent of GDP, } \\
1999\end{array}$ & $\begin{array}{c}\text { Gross interest } \\
\text { payments on public } \\
\text { debt in percent of } \\
\text { total tax revenues, } \\
1999\end{array}$ & $\begin{array}{c}\text { Interest payments } \\
\text { on public debt in } \\
\text { percent of total tax } \\
\text { revenues, average } \\
1970-1999\end{array}$ \\
\hline Italy & 116.60 & 6.85 & 14.75 & 17.32 \\
\hline Belgium & 115.90 & 7.05 & 14.97 & 17.64 \\
\hline Greece & 104.63 & 7.44 & 17.86 & 16.28 \\
\hline Spain & 72.45 & 3.63 & 9.75 & 6.48 \\
\hline Austria & 65.18 & 3.90 & 8.03 & 6.41 \\
\hline France & 64.97 & 3.35 & 6.65 & 4.90 \\
\hline Sweden & 63.47 & 5.31 & 9.18 & 8.53 \\
\hline Netherlands & 62.56 & 4.45 & 10.30 & 10.75 \\
\hline Germany & 60.18 & 3.52 & 7.88 & 5.66 \\
\hline United Kingdom $^{\mathrm{c}}$ & 56.99 & 2.81 & 6.97 & 8.58 \\
\hline Portugal & 55.90 & 3.11 & 7.55 & 12.50 \\
\hline Denmark $^{a}$ & 55.13 & 4.57 & 8.00 & 11.47 \\
\hline Ireland $^{\mathrm{b}}$ & 50.14 & 2.75 & 8.49 & 19.34 \\
\hline Finland & 46.62 & 3.54 & 7.21 & 4.06 \\
\hline
\end{tabular}

Source: OECD Economic Outlook. a) the average debt service per total revenue is for the years $1988 \mathrm{t}$ o1999. b) the average debt service per total revenue is for the years $1977 \mathrm{t}$ o1999. c) the average debt service per total revenue is for the years $1987 \mathrm{t}$ o1999.

Table 2: Descriptive Statistics for the Uncovered Interest Parity Differential (CIP) for EU Countries Based on own calculations, Max Sample 1977-1998

\begin{tabular}{|c|c|c|c|c|c|c|c|c|}
\hline & Mean & Median & Maxi-mum & Minimum & $\begin{array}{l}\text { Std. } \\
\text { Dev. }\end{array}$ & Skewness & $\begin{array}{c}\text { Kurto- } \\
\text { sis }\end{array}$ & $\begin{array}{c}\text { Observa- } \\
\text { tions }\end{array}$ \\
\hline Austria & 0.44 & 0.25 & 1.83 & 0.03 & 0.57 & 1.76 & 4.48 & 12 \\
\hline Belgium & 0.52 & 0.15 & 3.60 & 0.04 & 0.93 & 2.50 & 8.12 & 18 \\
\hline Denmark & 0.41 & 0.27 & 1.75 & 0.09 & 0.46 & 2.32 & 7.27 & 12 \\
\hline Spain & 1.91 & 1.25 & 5.79 & 0.06 & 1.90 & 0.85 & 2.33 & 22 \\
\hline Finland & 0.13 & 0.18 & 0.19 & 0.02 & 0.09 & -0.70 & 1.50 & 3 \\
\hline France & 0.53 & 0.21 & 1.85 & 0.03 & 0.63 & 1.24 & 2.93 & 16 \\
\hline Greece & 1.89 & 0.96 & 3.88 & 0.85 & 1.72 & 0.70 & 1.50 & 3 \\
\hline Ireland & 0.24 & 0.22 & 0.36 & 0.09 & 0.09 & -0.10 & 1.88 & 9 \\
\hline Italy & 1.41 & 0.49 & 4.92 & 0.05 & 1.68 & 1.22 & 2.95 & 21 \\
\hline Netherlands & 0.08 & 0.07 & 0.23 & 0.01 & 0.05 & 1.83 & 6.30 & 14 \\
\hline Portugal & 0.97 & 0.61 & 2.63 & 0.11 & 0.90 & 1.00 & 2.53 & 7 \\
\hline Sweden & 0.43 & 0.36 & 1.71 & 0.09 & 0.39 & 2.18 & 7.62 & 17 \\
\hline United Kingdom & 0.27 & 0.28 & 0.42 & 0.17 & 0.07 & 0.52 & 3.48 & 13 \\
\hline
\end{tabular}


Table 3: Descriptive Statistics for Average Effective Tax Rates for EU Countries ${ }^{\mathrm{a}}$, Sample 1980-1999

\begin{tabular}{|c|c|c|c|c|c|c|c|c|}
\hline & Mean & $\begin{array}{l}\text { Me- } \\
\text { dian } \\
\end{array}$ & $\begin{array}{c}\text { Maxi- } \\
\text { mum }\end{array}$ & $\begin{array}{l}\text { Mini- } \\
\text { mum }\end{array}$ & $\begin{array}{l}\text { Std. } \\
\text { Dev. }\end{array}$ & $\begin{array}{c}\text { Skew- } \\
\text { ness }\end{array}$ & $\begin{array}{c}\text { Kurto- } \\
\text { sis }\end{array}$ & $\begin{array}{c}\text { Observa- } \\
\text { tions }\end{array}$ \\
\hline \multicolumn{9}{|l|}{ Capital Tax } \\
\hline Austria & 45.37 & 45.39 & 60.59 & 37.69 & 5.37 & 1.08 & 4.69 & 18 \\
\hline Belgium & 47.42 & 47.86 & 53.36 & 40.21 & 3.96 & -0.24 & 2.05 & 18 \\
\hline Germany & 40.77 & 39.81 & 50.61 & 30.82 & 5.88 & 0.21 & 2.10 & 18 \\
\hline Denmark & 75.17 & 68.22 & 108.72 & 66.09 & 14.63 & 1.61 & 4.11 & 9 \\
\hline Spain & 29.15 & 29.19 & 35.17 & 22.06 & 4.39 & -0.21 & 1.86 & 18 \\
\hline Finland & 45.43 & 40.21 & 105.90 & 29.59 & 19.31 & 2.23 & 7.00 & 18 \\
\hline France & 45.12 & 42.57 & 56.66 & 39.53 & 5.84 & 0.80 & 2.08 & 18 \\
\hline Greece & 38.66 & 37.07 & 50.80 & 31.44 & 6.18 & 0.85 & 2.70 & 9 \\
\hline Ireland & 39.46 & 30.54 & 101.93 & 23.83 & 21.29 & 1.95 & 5.74 & 18 \\
\hline Italy & 42.45 & 40.52 & 58.24 & 30.06 & 7.16 & 0.57 & 2.86 & 18 \\
\hline Netherlands & 39.68 & 40.49 & 47.65 & 31.13 & 4.42 & -0.34 & 2.53 & 18 \\
\hline Portugal & 20.80 & 20.38 & 25.06 & 16.39 & 2.83 & -0.03 & 1.98 & 9 \\
\hline Sweden & 65.84 & 63.73 & 95.73 & 45.92 & 13.59 & 0.67 & 2.63 & 18 \\
\hline United & & & & & & & & 18 \\
\hline Kingdom & 83.57 & 87.20 & 113.44 & 58.86 & 15.09 & -0.10 & 2.25 & \\
\hline \multicolumn{9}{|l|}{ Labor Tax } \\
\hline Austria & 36.27 & 35.37 & 42.21 & 33.42 & 2.62 & 1.02 & 2.82 & 18 \\
\hline Belgium & 39.11 & 39.44 & 40.99 & 36.34 & 1.32 & -0.80 & 2.84 & 18 \\
\hline Germany & 34.69 & 34.85 & 37.15 & 32.44 & 1.41 & -0.07 & 1.93 & 18 \\
\hline Denmark & 42.06 & 41.82 & 44.78 & 39.95 & 1.81 & 0.20 & 1.46 & 10 \\
\hline Spain & 27.57 & 28.29 & 31.10 & 22.55 & 2.93 & -0.36 & 1.61 & 18 \\
\hline Finland & 38.77 & 38.01 & 48.85 & 31.58 & 5.65 & 0.40 & 1.90 & 18 \\
\hline France & 38.29 & 38.80 & 40.98 & 33.83 & 2.29 & -0.77 & 2.42 & 18 \\
\hline Greece & 23.12 & 21.99 & 27.56 & 20.16 & 2.44 & 0.35 & 1.92 & 11 \\
\hline Ireland & 23.69 & 24.48 & 26.60 & 18.29 & 2.34 & -1.33 & 3.84 & 18 \\
\hline Italy & 31.72 & 31.68 & 38.88 & 25.29 & 3.65 & 0.17 & 2.54 & 18 \\
\hline Netherlands & 41.31 & 41.66 & 43.55 & 37.62 & 1.81 & -0.61 & 2.31 & 18 \\
\hline Portugal & 22.34 & 22.77 & 23.72 & 20.34 & 1.14 & -0.54 & 2.02 & 9 \\
\hline Sweden & 48.65 & 48.15 & 52.63 & 45.24 & 2.33 & 0.28 & 1.83 & 18 \\
\hline $\begin{array}{c}\text { United } \\
\text { Kingdom }\end{array}$ & 22.46 & 22.18 & 25.60 & 20.41 & 1.66 & 0.40 & 1.78 & 18 \\
\hline \multicolumn{9}{|l|}{$\begin{array}{c}\text { Consumption } \\
\text { Tax }\end{array}$} \\
\hline Austria & 16.79 & 16.90 & 17.66 & 15.01 & 0.68 & -0.92 & 3.62 & 18 \\
\hline Belgium & 15.00 & 14.99 & 16.44 & 14.06 & 0.75 & 0.45 & 2.07 & 18 \\
\hline Germany & 13.13 & 13.08 & 14.41 & 12.39 & 0.55 & 0.61 & 2.90 & 18 \\
\hline Denmark & 20.85 & 20.80 & 22.85 & 19.59 & 0.85 & 0.74 & 3.08 & 18 \\
\hline Spain & 10.74 & 12.07 & 12.65 & 6.15 & 2.28 & -1.00 & 2.38 & 18 \\
\hline Finland & 18.78 & 18.61 & 20.75 & 17.75 & 0.86 & 0.98 & 3.00 & 18 \\
\hline France & 15.60 & 15.72 & 16.19 & 14.61 & 0.45 & -0.84 & 2.76 & 18 \\
\hline Greece & 14.89 & 15.13 & 16.80 & 12.30 & 1.27 & -0.47 & 2.40 & 18 \\
\hline Ireland & 18.60 & 18.91 & 20.12 & 15.32 & 1.21 & -1.42 & 4.52 & 18 \\
\hline Italy & 12.54 & 12.80 & 14.67 & 10.28 & 1.35 & -0.29 & 1.85 & 18 \\
\hline Netherlands & 15.05 & 15.47 & 16.28 & 13.30 & 0.96 & -0.58 & 1.96 & 18 \\
\hline Portugal & 16.27 & 16.93 & 18.46 & 13.58 & 1.57 & -0.47 & 1.77 & 18 \\
\hline Sweden & 15.83 & 15.88 & 17.46 & 14.19 & 1.08 & -0.05 & 1.69 & 18 \\
\hline United & & & & & & & & 18 \\
\hline Kingdom & 14.15 & 14.20 & 15.02 & 13.00 & 0.53 & -0.21 & 2.62 & \\
\hline
\end{tabular}

a: Own calculations Based on Carey and Tchilinguirian (2000) 
Table 4: Descriptive Statistics for Average Effective Labor and Consumption Tax Rates in percent of the Average Effective Capital Tax Rate for EU Countries ${ }^{\mathrm{a}}$, Sample 1980-1999.

\begin{tabular}{|c|c|c|c|c|c|c|c|c|}
\hline & Mean & Median & $\begin{array}{l}\text { Maxi- } \\
\text { Mum }\end{array}$ & $\begin{array}{l}\text { Mini- } \\
\text { mum }\end{array}$ & $\begin{array}{l}\text { Std. } \\
\text { Dev. }\end{array}$ & $\begin{array}{c}\text { Skew- } \\
\text { ness }\end{array}$ & $\begin{array}{c}\text { Kurto- } \\
\text { sis }\end{array}$ & $\begin{array}{l}\text { Obser- } \\
\text { vations }\end{array}$ \\
\hline \multicolumn{9}{|l|}{$\begin{array}{l}\text { Effective labor to } \\
\text { capital tax rate }\end{array}$} \\
\hline Austria & 81.24 & 78.69 & 106.26 & 56.49 & 13.21 & 0.46 & 2.74 & 18 \\
\hline Belgium & 83.09 & 83.57 & 94.94 & 68.52 & 8.07 & -0.32 & 2.12 & 18 \\
\hline Germany & 87.19 & 89.29 & 117.60 & 64.09 & 15.64 & 0.21 & 2.16 & 18 \\
\hline Denmark & 57.47 & 59.16 & 66.62 & 36.98 & 10.27 & -1.01 & 2.78 & 9 \\
\hline Spain & 95.46 & 93.83 & 110.84 & 82.06 & 8.35 & 0.25 & 1.98 & 18 \\
\hline Finland & 93.67 & 92.72 & 145.74 & 37.61 & 26.08 & -0.18 & 3.33 & 18 \\
\hline France & 86.60 & 92.43 & 101.93 & 61.37 & 14.39 & -0.69 & 1.86 & 18 \\
\hline Greece & 58.92 & 59.33 & 72.83 & 41.03 & 8.53 & -0.62 & 3.75 & 9 \\
\hline Ireland & 72.41 & 82.40 & 103.61 & 17.94 & 26.03 & -0.93 & 2.67 & 18 \\
\hline Italy & 75.54 & 76.21 & 84.69 & 60.46 & 6.88 & -0.87 & 3.19 & 18 \\
\hline Netherlands & 105.56 & 105.78 & 136.27 & 82.08 & 14.39 & 0.57 & 2.85 & 18 \\
\hline Portugal & 108.72 & 109.20 & 124.16 & 93.47 & 11.52 & -0.06 & 1.42 & 9 \\
\hline Sweden & 76.36 & 76.49 & 105.13 & 53.75 & 13.37 & 0.27 & 2.79 & 18 \\
\hline United Kingdom & 27.52 & 26.37 & 36.16 & 21.70 & 4.13 & 0.52 & 2.32 & 18 \\
\hline \multicolumn{9}{|c|}{$\begin{array}{l}\text { Effective consumption } \\
\text { to capital tax rate }\end{array}$} \\
\hline Austria & 37.40 & 38.02 & 45.44 & 28.11 & 3.80 & -0.42 & 3.84 & 18 \\
\hline Belgium & 31.89 & 32.58 & 37.41 & 26.51 & 3.46 & -0.15 & 1.87 & 18 \\
\hline Germany & 32.96 & 32.45 & 43.53 & 25.21 & 5.72 & 0.39 & 1.98 & 18 \\
\hline Denmark & 28.12 & 29.90 & 31.87 & 20.28 & 3.81 & -1.15 & 3.01 & 9 \\
\hline Spain & 36.64 & 36.95 & 43.48 & 27.31 & 4.95 & -0.39 & 2.19 & 18 \\
\hline Finland & 45.58 & 46.54 & 61.98 & 17.63 & 11.01 & -1.36 & 4.44 & 18 \\
\hline France & 35.06 & 36.48 & 39.96 & 27.61 & 4.05 & -0.67 & 2.05 & 18 \\
\hline Greece & 41.14 & 42.67 & 49.43 & 29.45 & 6.75 & -0.50 & 2.12 & 9 \\
\hline Ireland & 56.06 & 59.41 & 79.82 & 15.03 & 18.67 & -0.89 & 2.94 & 18 \\
\hline Italy & 29.91 & 30.01 & 35.18 & 23.66 & 3.05 & -0.25 & 2.92 & 18 \\
\hline Netherlands & 38.38 & 38.80 & 45.93 & 28.94 & 4.87 & -0.36 & 2.37 & 18 \\
\hline Portugal & 83.35 & 78.82 & 106.49 & 69.47 & 12.16 & 0.68 & 2.34 & 9 \\
\hline Sweden & 24.76 & 24.49 & 32.98 & 18.24 & 4.09 & 0.45 & 2.43 & 18 \\
\hline United Kingdom & 17.56 & 16.20 & 24.49 & 11.84 & 3.78 & 0.51 & 1.97 & 18 \\
\hline
\end{tabular}

a: Own calculations based on Carey and Tchilinguirian (2000) 


\section{Regression and Robustness Tests, Hypothesis 1 and 2.}

Table 5: Results for the regression of taxes and expenditures, basic specification. Sample: 1973-1999

\begin{tabular}{|c|c|c|c|c|}
\hline & $\triangle T A X / G D P$ & $\triangle E X P / G D P$ & $\triangle T A X / G D P$ & $\triangle E X P / G D P$ \\
\hline$\Delta \mathrm{BY}_{-1}$ & $0.013(1.40)$ & $0.010(0.78)$ & $0.021\left(2.41^{* *}\right)$ & $-0.013(-1.18)$ \\
\hline$\Delta \mathrm{DS}_{-1}$ & $0.200\left(3.04^{* * *}\right)$ & $-0.366\left(-3.92^{* * *}\right)$ & & \\
\hline $\mathrm{ADS}_{2}$ & & & $0.065\left(2.54^{* *}\right)$ & $-0.047(1.32)$ \\
\hline$\triangle \mathrm{UB}$ & $0.060(1.61)$ & $0.344\left(7.56^{* * *}\right)$ & $0.065\left(1.73^{*}\right)$ & $0.353\left(7.62^{* * *}\right)$ \\
\hline AGR & $-0.091\left(-6.98^{* * *}\right)$ & $-0.275\left(-16.2^{* * *}\right)$ & $-0.092\left(-6.85^{* * *}\right)$ & $-0.264\left(-15.5^{* * *}\right)$ \\
\hline${A \mathrm{GR}_{-1}}$ & $-0.053\left(-4.11^{* * *}\right)$ & $-0.174\left(-10.7^{* * *}\right)$ & $-0.026(-1.62)$ & $-0.177\left(-8.26^{* * *}\right)$ \\
\hline AINFL & $0.018(1.43)$ & $0.066\left(3.31^{* * *}\right)$ & $0.018(1.37)$ & $0.070\left(3.49^{* * *}\right)$ \\
\hline AINFL $_{-1}$ & $0.040\left(3.06^{* * *}\right)$ & $0.041\left(2.06^{* *}\right)$ & $0.065\left(5.09^{* * *}\right)$ & $0.020(1.05)$ \\
\hline MAAS & $-0.074(-0.95)$ & $-0.391\left(-3.83^{* * *}\right)$ & $-0.137\left(-1.71^{*}\right)$ & $-0.284\left(-2.84^{* * *}\right)$ \\
\hline Obs. & 309 & 293 & 309 & 293 \\
\hline Wald $^{\mathrm{a}, \mathrm{c}}$ & $X^{2}=123.9$ & $\chi^{2}=707.8$ & $\chi^{2}=139.6$ & $\chi^{2}=686.0$ \\
\hline & $(0.000)$ & $(0.000)$ & $(0.000)$ & $(0.000)$ \\
\hline DW & 2.10 & 2.47 & 2.09 & 2.47 \\
\hline $\mathrm{R}^{2}$ & 0.08 & 0.25 & 0.08 & 0.24 \\
\hline Hausman Test ${ }^{\mathrm{a}}$ & $\chi^{2}=8.26(0.41)$ & $\chi^{2}=0.48(0.99)$ & $\chi^{2}=1.77(0.98)$ & $\chi^{2}=4.71(0.79)$ \\
\hline F-test for $D S 2^{a, d}$ & & & $\mathrm{~F}=4.81(0.029)$ & $\mathrm{F}=8.17(0.005)$ \\
\hline
\end{tabular}

MAAS is a dummy for the introduction of the Maastricht treaty, taking the value 1 from 1993 and onwards. T-stats are in parentheses and * means significant on a $10 \%$ level, $* *$ on a $5 \%$ level and *** on a $1 \%$ level. The Hausman tests are carried out as suggested in Greene. a) Numbers in parentheses after test statistics are p-values. b) In the regression using DS2 but splitting up DS2 into the interest rate term and the growth term, the $\mathrm{F}$ test statistic is for the restriction that the parameter estimate of the interest rate term is equal to minus the parameter estimate of the growth-debt interaction term, which would the use of $D S 2$. In the unrestricted regression, the growth-debt interaction term is never significant. c) Wald Test for significance of regression (i.e. join significance of the slope parameter estimates).

Table 6: Results for the regression of taxes and expenditures including the Maastricht dummy interacted with debt service. Sample: 1973-1999

\begin{tabular}{|c|c|c|c|c|}
\hline & $\triangle T A X / G D P$ & $\triangle E X P / G D P$ & $\triangle T A X / G D P$ & $\triangle E X P / G D P$ \\
\hline$\Delta \mathrm{BY}_{-1}$ & $0.014(1.41)$ & $0.009(0.71)$ & $0.020(2.22 * *)$ & $-0.016(-1.38)$ \\
\hline $\operatorname{ADS1}_{-1}$ & $0.185\left(2.23^{* *}\right)$ & $-0.424\left(-3.86^{* * *}\right)$ & & \\
\hline $\mathrm{MAAS}^{*} \boldsymbol{A D S} 1_{-1}$ & $0.043(0.33)$ & $0.152(0.79)$ & & \\
\hline$A \mathrm{DS} 2_{-1}$ & & & $0.048(1.48)$ & $-0.082\left(-1.98^{* *}\right)$ \\
\hline $\mathrm{MAAS}^{*} \boldsymbol{A D S} 2_{-1}$ & & & $0.041(0.95)$ & $0.071(1.31)$ \\
\hline AUB & $0.062(1.64)$ & $0.345\left(7.47^{* * *}\right)$ & $0.065\left(1.70^{*}\right)$ & $0.346\left(7.42^{* * *}\right)$ \\
\hline \multirow[t]{2}{*}{$\triangle \mathrm{GR}$} & $-0.091\left(-6.84^{* * *}\right)$ & $-0.275\left(-16.1^{* * *}\right)$ & $-0.091(-$ & $-0.263\left(-15.4^{* * *}\right)$ \\
\hline & & & $\left.6.74^{* * *}\right)$ & \\
\hline$\Delta \mathrm{GR}_{-1}$ & $-0.052\left(-3.96^{* * *}\right)$ & $-0.174\left(-10.6^{* * *}\right)$ & $-0.028\left(-1.72^{*}\right)$ & $-0.180\left(-8.44^{* * *}\right)$ \\
\hline$\triangle \mathrm{INFL}$ & $0.019(1.41)$ & $0.064\left(3.14^{* * *}\right)$ & $0.017(1.29)$ & $0.065\left(3.18^{* * *}\right)$ \\
\hline AINFL $_{-1}$ & $0.040\left(3.03^{* * *}\right)$ & $0.042\left(2.09^{* *}\right)$ & $0.065\left(4.98^{* * *}\right)$ & $0.017(0.88)$ \\
\hline MAAS & $-0.072(-0.89)$ & $-0.394\left(-3.70^{* * *}\right)$ & $-0.133\left(-1.66^{*}\right)$ & $-0.296\left(-2.80^{* * *}\right)$ \\
\hline DW & 2.09 & 2.45 & 2.08 & 2.45 \\
\hline
\end{tabular}


Table 7: Robustness of the parameter estimates for the debt service term to changes in the panel members (dropping one country at the time). Sample: 1973-1999

\begin{tabular}{|ccc|}
\hline & \multicolumn{1}{c}{$\boldsymbol{\Lambda T A X / G D P}$} & AEXP/GDP \\
\hline AT & $0.159\left(2.28^{* *}\right)$ & $-0.363\left(-3.39^{* * *}\right)$ \\
\hline BE & $0.184\left(1.93^{* *}\right)$ & $-0.379\left(-3.24^{* * *}\right)$ \\
DE & $0.226\left(3.23^{* * *}\right)$ & $-0.355\left(-3.58^{* * *}\right)$ \\
DK & $0.184\left(2.71^{* * *}\right)$ & $-0.372\left(-3.96^{* * *}\right)$ \\
ES & $0.222\left(2.95^{* * *}\right)$ & $-0.353\left(-3.11^{* * *}\right)$ \\
FR & $0.174\left(2.41^{* *}\right)$ & $-0.409\left(-3.87^{* * *}\right)$ \\
GR & $0.279\left(3.71^{* * *}\right)$ & $-0.587\left(-5.79^{* * *}\right)$ \\
IE & $0.217\left(3.09^{* * *}\right)$ & $-0.357\left(-3.49^{* * *}\right)$ \\
IT & $0.162\left(1.86^{*}\right)$ & $-0.412\left(-3.85^{* * *}\right)$ \\
NL & $0.195\left(2.72^{* * *}\right)$ & $-0.360\left(-3.35^{* * *}\right)$ \\
PT & $0.328\left(3.97^{* * *}\right)$ & $-0.244\left(1.72^{*}\right)$ \\
\hline SE & $0.185\left(2.74^{* * *}\right)$ & $-0.306\left(-3.03^{* * *}\right)$ \\
UK & $0.160\left(2.24^{* *}\right)$ & $-0.381\left(-3.72^{* * *}\right)$ \\
\hline DK,GR & & $-0.609\left(-5.98^{* * *}\right)$ \\
\hline ES, PT & $0.348\left(3.51^{* * *}\right)$ & \\
\hline
\end{tabular}

Table 8: Robustness of parameter estimates to the inclusion of other explanatory variables. Sample: 1973-1999

\begin{tabular}{|c|c|c|c|c|}
\hline & $\triangle T A X / G D P$ & $\triangle E X P / G D P$ & $\triangle T A X / G D P$ & $\triangle E X P / G D P$ \\
\hline$\Delta \mathrm{BY}_{-1}$ & $0.020\left(1.65^{*}\right)$ & $-0.050\left(-3.12^{* * *}\right)$ & $0.010(0.96)$ & $0.023\left(1.83^{*}\right)$ \\
\hline$\triangle D S 1_{-1}$ & $0.257\left(3.46^{* * *}\right)$ & $-0.197\left(-1.95^{* *}\right)$ & $0.197\left(2.91^{* * *}\right)$ & $-0.385\left(-4.05^{* * *}\right)$ \\
\hline AUB & $0.040(1.00)$ & $0.449\left(9.32^{* * *}\right)$ & $0.044(1.14)$ & $0.455\left(9.50^{* * *}\right)$ \\
\hline$\triangle \mathrm{GR}$ & $-0.115\left(-6.86^{* * *}\right)$ & $-0.251\left(-12.3^{* * *}\right)$ & $-0.092\left(-7.15^{* * *}\right)$ & $-0.268\left(-15.2^{* * *}\right)$ \\
\hline$\Delta \mathrm{GR}_{-1}$ & $-0.047\left(-2.90^{* * *}\right)$ & $-0.125\left(-6.61^{* * *}\right)$ & $-0.050\left(-3.90^{* * *}\right)$ & $-0.161\left(-9.61^{* * *}\right)$ \\
\hline AINFL & $0.021(1.42)$ & $0.006(0.31)$ & $0.018(1.37)$ & $0.077\left(4.08^{* * *}\right)$ \\
\hline $\mathbb{A N F L}_{-1}$ & $0.038\left(2.74^{* * *}\right)$ & $-0.009(-0.47)$ & $0.041\left(3.20^{* * *}\right)$ & $0.041\left(2.26^{* *}\right)$ \\
\hline MAAS & $-0.021(-0.24)$ & $-0.440\left(-4.10^{* * *}\right)$ & $-0.181\left(-2.07^{* *}\right)$ & $-0.547\left(-5.12^{* * *}\right)$ \\
\hline APART & $0.157\left(2.56^{* *}\right)$ & $0.140\left(2.42^{* *}\right)$ & & \\
\hline$\triangle O L D$ & $-0.442\left(-1.97^{* *}\right)$ & $-0.648\left(-2.38^{* *}\right)$ & & \\
\hline$\triangle \mathrm{OPEN}$ & $-0.0001\left(-1.68^{*}\right)$ & $0.0002\left(3.54^{* * *}\right)$ & & \\
\hline EYEAR & & & $-0.228\left(-3.04^{* * *}\right)$ & $-0.039(-0.52)$ \\
\hline EYEAR $_{-1}$ & & & $0.343\left(4.52^{* * *}\right)$ & $-0.163\left(-2.25^{* *}\right)$ \\
\hline$\triangle I D E O$ & & & $-0.093(-1.32)$ & $-0.052(-0.65)$ \\
\hline DW & 2.10 & 1.98 & 1.93 & 2.54 \\
\hline
\end{tabular}


Table 9: Robustness of parameter estimates to the inclusion of interest rate changes.

Sample: 1973-1999

\begin{tabular}{|c|c|c|c|c|}
\hline & $\triangle T A X / G D P$ & $\triangle E X P / G D P$ & $\triangle T A X / G D P^{a}$ & $\triangle E X P / G D P^{a}$ \\
\hline$\Delta \mathrm{BY}_{-1}$ & $0.022\left(2.27^{* *}\right)$ & $0.017(1.50)$ & $0.004(0.29)$ & $0.036\left(-2.48^{* *}\right)$ \\
\hline$\Delta \mathrm{DS}_{-1}$ & $0.207\left(3.08^{* * *}\right)$ & $-0.421\left(-4.70^{* * *}\right)$ & $0.267\left(3.19^{* * *}\right)$ & $-0.616\left(-5.85^{* * *}\right)$ \\
\hline$\triangle \mathrm{UB}$ & 0.053 (1.39) & $0.341\left(8.04^{* * *}\right)$ & $0.024(0.54)$ & $0.294\left(5.79^{* * *}\right)$ \\
\hline$\Delta \mathrm{GR}$ & $-0.073\left(-5.08^{* * *}\right)$ & $-0.252\left(-16.3^{* * *}\right)$ & $-0.099\left(-6.11^{* * *}\right)$ & $-0.292\left(-15.4^{* * *}\right)$ \\
\hline $\operatorname{AGR}_{-1}$ & $-0.035\left(-2.50^{* *}\right)$ & $-0.170\left(-11.2^{* * *}\right)$ & $-0.082\left(-5.22^{* * *}\right)$ & $-0.220\left(-11.8^{* * *}\right)$ \\
\hline AINFL & $0.020(1.55)$ & $0.057\left(3.07^{* * *}\right)$ & $0.007(0.44)$ & $0.020(0.889)$ \\
\hline$\Delta \mathrm{INFL}_{-1}$ & $0.034\left(2.37^{* *}\right)$ & $-0.008(-0.43)$ & $0.010(0.59)$ & $0.018(0.72)$ \\
\hline MAAS & $-0.054(-0.67)$ & $-0.237\left(-2.91^{* * *}\right)$ & $-0.002(-0.02)$ & $-0.395\left(-3.61^{* * *}\right)$ \\
\hline DIRS $_{-1}$ & $0.027(1.48)$ & $0.118\left(6.48^{* * *}\right)$ & & \\
\hline DIRL $_{-1}$ & & & $0.034(1.17)$ & $0.082\left(2.30^{* *}\right)$ \\
\hline DW & 2.15 & 2.47 & 2.12 & 2.41 \\
\hline
\end{tabular}

a) Excluding Greece from the pool due to lack of data on long term interest rates. The change in the parameter estimates are mostly due to this exclusion, see sequential exclusion of countries above.

Table 10: Robustness of parameter estimates to the inclusion of two additional lags of the explanatory variables, and for the first differenced specification with growth and inflation in levels ${ }^{\text {a. }}$ Sample: 1973-1999

\begin{tabular}{|c|c|c|c|c|}
\hline & $\triangle T A X / G D P$ & $\triangle E X P / G D P$ & $\triangle T A X / G D P$ & $\triangle E X P / G D P$ \\
\hline$\Delta \mathrm{BY}_{-1}$ & $0.010(1.09)$ & $0.042\left(3.27^{* * *}\right)$ & $0.001(0.20)$ & $-0.022\left(-1.72^{*}\right)$ \\
\hline$A \mathrm{DS}_{-1}$ & $0.164\left(2.62^{* * *}\right)$ & $-0.280\left(-3.10^{* * *}\right)$ & $0.223\left(3.61^{* * *}\right)$ & $-0.284\left(-2.83^{* * *}\right)$ \\
\hline$\Delta \mathrm{DS}_{-2}$ & $0.076(1.23)$ & $-0.573\left(-6.25^{* * *}\right)$ & & \\
\hline$\triangle \mathrm{DS}_{-3}$ & $-0.119\left(-1.90^{*}\right)$ & $-0.260\left(-2.75^{* * *}\right)$ & & \\
\hline AUB & $0.026(0.64)$ & $0.161\left(3.46^{* * *}\right)$ & $0.011(0.28)$ & $0.288\left(5.42^{* * *}\right)$ \\
\hline$\Delta \mathrm{GR}$ & $-0.105\left(-6.37^{* * *}\right)$ & $-0.320\left(-15.6^{* * *}\right)$ & & \\
\hline$\Delta \mathrm{GR}_{-1}$ & $-0.068\left(-3.65^{* * *}\right)$ & $-0.222\left(-9.73^{* * *}\right)$ & & \\
\hline$\Delta \mathrm{GR}_{-2}$ & $-0.023(-1.29)$ & $-0.102\left(-4.67^{* * *}\right)$ & & \\
\hline$\Delta \mathrm{GR}_{-3}$ & $-0.002(-1.18)$ & $-0.072\left(-4.11^{* * *}\right)$ & & \\
\hline GR & & & $-0.096\left(-5.59^{* * *}\right)$ & $\begin{array}{l}-0.282(- \\
\left.12.74^{* * *}\right)\end{array}$ \\
\hline $\mathrm{GR}_{-1}$ & & & $0.047\left(2.61^{* * *}\right)$ & $0.110\left(5.16^{* * *}\right)$ \\
\hline$\triangle I N F L$ & $0.021(1.50)$ & $0.040\left(2.06^{* *}\right)$ & & \\
\hline $\mathbb{I N F L}_{-1}$ & $0.027\left(1.88^{*}\right)$ & $0.012(0.63)$ & & \\
\hline $\mathbf{A N F L}_{-2}$ & $0.001(0.07)$ & $0.094\left(4.97^{* * *}\right)$ & & \\
\hline $\mathbf{I N F L}_{-3}$ & $-0.009(-0.70)$ & $0.019(1.04)$ & & \\
\hline INFL & & & $0.050\left(3.85^{* * *}\right)$ & $0.111\left(5.09^{* * *}\right)$ \\
\hline INFL-1 $_{-1}$ & & & $-0.013\left(-0.91^{* * *}\right)$ & $-0.063\left(-2.76^{* * *}\right)$ \\
\hline MAAS & $-0.138\left(-1.87^{*}\right)$ & $-0.587\left(-5.85^{* * *}\right)$ & $0.118(1.23)$ & $-0.315\left(-2.63^{* * *}\right)$ \\
\hline DW & 2.18 & 2.59 & & \\
\hline
\end{tabular}

a: debt to GDP, debt service to GDP and unemployment are included in first differences, while growth and inflation, which are found likely to be stationary, are included in levels. 
Table 11: Robustness of parameter estimates to the specification: Results for the specification in LEVELS ${ }^{\text {a. }}$ Sample: 1973-1999

\begin{tabular}{|ccc|}
\hline & TAX/GDP & EXP/GDP \\
\hline Dependent $_{-1}$ & $0.459\left(17.04^{* * *}\right)$ & $0.634\left(20.3^{* * *}\right)$ \\
\hline BY $_{-1}$ & $-0.015(-3.26)$ & $-0.056\left(-7.18^{* * *}\right)$ \\
\hline DS1 $_{-1}$ & $0.300\left(7.94^{* * *}\right)$ & $0.018(0.28)$ \\
\hline UB & $0.066\left(3.72^{* * *}\right)$ & $0.301\left(8.22^{* * *}\right)$ \\
GR & $-0.057\left(-4.13^{* *}\right)$ & $-0.301\left(-14.6^{* * *}\right)$ \\
\hline GR $_{-1}$ & $0.015(1.09)$ & $-0.032\left(-1.68^{*}\right)$ \\
\hline INFL $_{\text {INFL }}$ & $0.055\left(5.79^{* * *}\right)$ & $0.211\left(11.7^{* * *}\right)$ \\
\hline MAAS & $-0.036\left(-4.47^{* * *}\right)$ & $-0.042\left(-2.33^{* *}\right)$ \\
\hline
\end{tabular}

a) A country specific linear time trend and fixed effects are included but not shown.

Table 12. The percentage point change in overall taxes and expenditures due to debt service in 1999 according to parameter estimates, percent.

\begin{tabular}{|c|c|c|c|}
\hline Taxes & $b^{a}=0.20$ & $b=0.00$ & $b=0.34$ \\
\hline Austria & 1.76 & 0.00 & 3.07 \\
\hline Belgium & 3.11 & 0.00 & 5.41 \\
\hline Germany & 1.87 & 0.00 & 3.25 \\
\hline Denmark & 1.81 & 0.00 & 3.15 \\
\hline Spain & 2.07 & 0.00 & 3.60 \\
\hline France & 1.46 & 0.00 & 2.54 \\
\hline Greece $^{\mathrm{b}}$ & 4.89 & 0.00 & 8.51 \\
\hline Ireland & 1.73 & 0.00 & 3.00 \\
\hline Italy & 3.18 & 0.00 & 5.54 \\
\hline The Netherlands & 2.21 & 0.00 & 3.84 \\
\hline Portugal & 1.80 & 0.00 & 3.14 \\
\hline Sweden & 2.04 & 0.00 & 3.54 \\
\hline United Kingdom & 1.53 & 0.00 & 2.67 \\
\hline Expenditures: & $b^{a}=-0.366$ & $b=-0.197$ & $b=-1$ \\
\hline Austria & -3.06 & -1.64 & -8.35 \\
\hline Belgium & -6.33 & -3.41 & -17.31 \\
\hline Germany & -3.06 & -1.64 & -8.35 \\
\hline Denmark & -3.37 & -1.81 & -9.21 \\
\hline Spain & -3.83 & -2.06 & -10.46 \\
\hline France & -2.52 & -1.35 & -6.87 \\
\hline Greece $^{b}$ & -8.75 & -4.71 & -23.90 \\
\hline Ireland & -3.60 & -1.94 & -9.82 \\
\hline Italy & -6.04 & -3.25 & -16.51 \\
\hline The Netherlands & -4.26 & -2.29 & -11.63 \\
\hline Portugal & -2.85 & -1.53 & -7.79 \\
\hline Sweden & -3.84 & -2.07 & -10.50 \\
\hline United Kingdom & -2.82 & -1.52 & -7.72 \\
\hline
\end{tabular}

a). The first row contains the percentage point change due to debt service in 1999 when the regression coefficient of debt service in the basic regression is used. The two other rows show the same number for the lowest and the highest parameter estimates for the effect of debt service on the tax ratio found in the robustness analysis.

b) The number for Greece is calculated for 1997 due to lack of data. 


\section{Regression and Robustness Tests, Hypotheses 3 and 4.}

Table 13: Results for the specification including Icap. Sample: 1978-1999.

\begin{tabular}{|c|c|c|}
\hline & $\triangle T A X / G D P$ & $\triangle E X P / G D P$ \\
\hline$\Delta \mathrm{BY}_{-1}$ & $0.012(0.84)$ & $0.003(0.27)$ \\
\hline$\Delta \mathrm{DS}_{-1}$ & $0.431\left(4.54^{* * *}\right)$ & $-0.257\left(-2.39^{* *}\right)$ \\
\hline$\Delta\left(\mathrm{DS}_{-1} *-\mathrm{CIP}_{-1}\right)$ & $-0.007(-0.34)$ & $-0.086\left(-3.53^{* * *}\right)$ \\
\hline- CIP $_{-1}$ & $-0.149(-1.36)$ & $0.334\left(3.06^{* * *}\right)$ \\
\hline AUB & $-0.133\left(-2.86^{* * *}\right)$ & $0.379\left(7.85^{* * *}\right)$ \\
\hline$\triangle \mathrm{GR}$ & $-0.050\left(-1.82^{*}\right)$ & $-0.212\left(-9.3^{* * *}\right)$ \\
\hline $\operatorname{AGR}_{-1}$ & $-0.061\left(-2.63^{* *}\right)$ & $-0.140\left(-6.2^{* * *}\right)$ \\
\hline$\triangle I N F L$ & $0.037(1.41)$ & $0.019(0.73)$ \\
\hline $\mathbf{A N F L}_{-1}$ & $0.004(0.15)$ & $0.026(0.99)$ \\
\hline MAAS & $-0.005(-0.06)$ & $-0.285\left(-2.91^{* * *}\right)$ \\
\hline Obs. & 169 & 169 \\
\hline DW & 2.33 & 1.62 \\
\hline $\mathrm{R}^{2}$ & 0.14 & 0.39 \\
\hline
\end{tabular}

Table 14: Robustness of the parameter estimates for the interaction term to changes in the panel members (dropping one country at the time). Sample: 1978-1999.

\begin{tabular}{|c|cc|}
\hline & ATAX/GDP & AEXP/GDP \\
\hline AT & $-0.008(-0.38)$ & $-0.093\left(-3.69^{* * *}\right)$ \\
\hline BE & $-0.012(-0.49)$ & $-0.087\left(-2.88^{* * *}\right)$ \\
DE & $-0.015(-0.61)$ & $-0.075\left(-2.93^{* * *}\right)$ \\
\hline DK & $-0.003(-0.12)$ & $-0.049\left(-1.87^{*}\right)$ \\
ES & $-0.074\left(-2.01^{* *}\right)$ & $-0.077\left(-1.83^{*}\right)$ \\
\hline FR & $-0.006(-0.27)$ & $-0.082\left(-3.20^{* * *}\right)$ \\
\hline IE & $-0.009(-0.42)$ & $-0.088\left(-3.56^{* * *}\right)$ \\
\hline IT & $0.010(0.45)$ & $-0.125\left(-4.43^{* * *}\right)$ \\
NL & $-0.009(-0.43)$ & $-0.086\left(-3.38^{* *}\right)$ \\
PT & $-0.010(-0.41)$ & $-0.063\left(-2.38^{* *}\right)$ \\
SE & $-0.019(-0.89)$ & $-0.078\left(-2.74^{* * *}\right)$ \\
UK & $-0.006(-0.23)$ & $-0.092\left(-3.56^{* * *}\right)$ \\
\hline
\end{tabular}


Table 15: Robustness of parameter estimates to the inclusion of a time trend and the interest rate in the regression, and to the specification with growth and inflation in levels ${ }^{\text {a } . ~ S a m p l e: ~ 1978-1999 . ~}$

\begin{tabular}{|c|c|c|c|c|}
\hline & $\triangle T A X / G D P$ & $\triangle E X P / G D P$ & $\triangle T A X / G D P$ & $\triangle E X P / G D P$ \\
\hline$\Delta \mathrm{BY}_{-1}$ & $0.002(0.13)$ & $0.021(1.45)$ & $0.022(1.64)$ & $-0.004(-0.36)$ \\
\hline$\Delta \mathrm{DS}_{-1}$ & $0.383\left(3.59^{* * *}\right)$ & $-0.186\left(-1.81^{*}\right)$ & $0.416\left(4.27^{* * *}\right)$ & $-0.301\left(-2.91^{* * *}\right)$ \\
\hline$\Lambda\left(\mathrm{DS}_{-1} *-\mathrm{CIP}_{-1}\right)$ & $-0.002(-0.11)$ & $-0.096\left(-4.35^{* * *}\right)$ & $-0.021(-1.02)$ & $-0.101\left(-2.38^{* * *}\right)$ \\
\hline$-\mathrm{ACIP}_{-1}$ & $-0.223\left(-2.00^{* *}\right)$ & $0.364\left(3.38^{* * *}\right)$ & $-0.121(-1.26)$ & $0.361\left(3.52^{* * *}\right)$ \\
\hline AUB & $-0.136\left(-2.65^{* * *}\right)$ & $0.502\left(9.42^{* * *}\right)$ & $0.037(0.59)$ & $0.220\left(3.80^{* * *}\right)$ \\
\hline$\Delta \mathrm{GR}$ & $-0.031(-1.11)$ & $-0.209\left(-9.12^{* * *}\right)$ & & \\
\hline $\operatorname{AGR}_{-1}$ & $-0.054\left(-2.15^{* *}\right)$ & $\begin{array}{l}-0.113(- \\
\left.5.63^{* * *}\right)\end{array}$ & & \\
\hline GR & & & $0.075\left(2.06^{* *}\right)$ & $-0.268\left(-8.81^{* * *}\right)$ \\
\hline $\mathrm{GR}_{-1}$ & & & $0.107\left(-2.38^{* *}\right)$ & $0.095\left(3.25^{* * *}\right)$ \\
\hline$\triangle I N F L$ & $0.061\left(2.04^{* *}\right)$ & 0.047 (1.66) & & \\
\hline$\Delta \mathrm{INFL}_{-1}$ & $0.017(0.62)$ & $0.042(1.59)$ & & \\
\hline INFL & & & $0.059\left(2.29^{* *}\right)$ & $0.077\left(2.75^{* * *}\right)$ \\
\hline INFL $_{-1}$ & & & $0.004(0.163)$ & $0.012(0.46)$ \\
\hline MAAS & $-0.242(-1.54)$ & $-0.570\left(-3.33^{* * *}\right)$ & $0.348\left(2.97^{* * *}\right)$ & $-0.036(-0.30)$ \\
\hline Time & $0.018(0.96)$ & $0.005(0.26)$ & & \\
\hline$\triangle I R S$ & $-0.078\left(-2.78^{* * *}\right)$ & $-0.028(-1.02)$ & & \\
\hline DW & 2.16 & 1.90 & & \\
\hline
\end{tabular}

a: debt to GDP, debt service to GDP and unemployment are included in first differences, while growth and inflation, which are found likely to be stationary, are included in levels.

Table 16. Robustness of parameter estimates to the specification: Results for the regression estimated in LEVELS including the lagged explanatory variable and linear time trends. Sample: 1978-1999.

\begin{tabular}{|ccc|}
\hline & $\boldsymbol{T A X} / \boldsymbol{G D P}$ & $\boldsymbol{E X P} / \boldsymbol{G D P}$ \\
\hline LAG-DEP $\left.^{* * *}\right)$ & $0.437\left(10.7^{* *}\right)$ & $0.653\left(16.69^{* * *}\right)$ \\
\hline BY $_{-1}$ & $0.009(0.81)$ & $-0.048\left(-4.61^{* * *}\right)$ \\
DS1 $_{-1}$ & $0.193\left(-1.94^{* *}\right)$ & $-0.285\left(-3.27^{* * *}\right)$ \\
DS1 $_{-1^{*}}-\mathrm{CIP}_{-1}$ & $-0.147\left(-6.47^{* * *}\right)$ & $-0.059\left(-3.39^{* * *}\right)$ \\
\hline CIP $_{-1}$ & $0.481\left(3.43^{* *}\right)$ & $0.560\left(6.09^{* * *}\right)$ \\
\hline UB & $-0.047(-1.23)$ & $0.039(0.97)$ \\
GR & $-0.053\left(-2.19^{* *}\right)$ & $-0.317\left(-12.2^{* * *}\right)$ \\
GR $_{-1}$ & $0.028(1.27)$ & $-0.055\left(-2.60^{* * *}\right)$ \\
INFL $_{\text {INFL }}$ & $0.007(0.28)$ & $-0.047\left(-2.38^{* *}\right)$ \\
MAAS & $0.027(1.04)$ & $-0.022(-1.12)$ \\
\hline & $-0.299\left(-2.00^{* *}\right)$ & $0.010(0.05)$ \\
\hline
\end{tabular}




\section{Regression and Robustness Tests, Hypotheses 5 and 6}

Table 17: Results for the regression of effective tax ratios, specification including Icap. Sample: 1981-1997.

\begin{tabular}{|c|c|c|}
\hline & $\triangle L A B C A P$ & $\triangle C O N C A P$ \\
\hline$\Delta \mathrm{BY}_{-1}$ & $-0.077(-1.10)$ & $0.065\left(1.80^{*}\right)$ \\
\hline $\operatorname{ADS}_{-1}$ & $0.211(0.39)$ & $-0.438(-1.51)$ \\
\hline$\Delta\left(\mathrm{DS}_{-1} *-\mathrm{CIP}_{-1}\right)$ & $0.429\left(2.75^{* * *}\right)$ & $0.317\left(4.25^{* * *}\right)$ \\
\hline$-\triangle \mathrm{CIP}_{-1}$ & $-0.592(-0.64)$ & $-0.745\left(-1.96^{* *}\right)$ \\
\hline AUB & $0.868\left(2.93^{* * *}\right)$ & $0.443\left(3.00^{* * *}\right)$ \\
\hline$\triangle \mathrm{GR}$ & $1.073\left(7.69^{* * *}\right)$ & $0.569\left(8.03^{* * *}\right)$ \\
\hline $\mathrm{AGR}_{-1}$ & $0.428\left(3.24^{* * *}\right)$ & $0.176\left(2.55^{* *}\right)$ \\
\hline$\triangle I N F L$ & $-0.684\left(-3.78^{* * *}\right)$ & $-0.161\left(-1.83^{*}\right)$ \\
\hline $\mathbb{I N F L}_{-1}$ & $-0.627\left(-3.92^{* * *}\right)$ & $-0.085(1.13)$ \\
\hline MAAS & $-0.000(-0.00)$ & $-0.226(-0.72)$ \\
\hline Obs. & 139 & 141 \\
\hline DW & 2.44 & 2.54 \\
\hline $\mathrm{R}^{2}$ & 0.24 & 0.27 \\
\hline
\end{tabular}

Table 18: Robustness of the parameter estimates for the interaction term to changes in the panel members (dropping one country at the time). Sample: 1981-1997.

\begin{tabular}{|ccc|}
\hline & ALABCAP & ACONCAP \\
\hline AT & $0.427\left(2.72^{* * *}\right)$ & $0.310\left(4.14^{* * *}\right)$ \\
\hline BE & $0.324\left(1.70^{*}\right)$ & $0.355\left(4.06^{* * *}\right)$ \\
DE & $0.322\left(1.92^{* *}\right)$ & $0.215\left(2.58^{* *}\right)$ \\
\hline DK & $0.536\left(3.20^{* * *}\right)$ & $0.310\left(3.95^{* * *}\right)$ \\
\hline ES & $0.688\left(2.84^{* * *}\right)$ & $0.261\left(2.25^{* *}\right)$ \\
FR & $0.454\left(2.58^{* *}\right)$ & $0.356\left(4.12^{* * *}\right)$ \\
IE & $0.468\left(3.05^{* * *}\right)$ & $0.351\left(4.76^{* * *}\right)$ \\
IT & $0.438\left(2.55^{* *}\right)$ & $0.295\left(3.36^{* * *}\right)$ \\
NL & $0.456\left(2.80^{* * *}\right)$ & $0.339\left(4.41^{* * *}\right)$ \\
PT & $0.439\left(2.79^{* * *}\right)$ & $0.228\left(3.15^{* * *}\right)$ \\
SE & $0.373\left(2.34^{* *}\right)$ & $0.331\left(4.10^{* * *}\right)$ \\
\hline UK & $0.386\left(2.36^{* *}\right)$ & $0.300\left(3.80^{* * *}\right)$ \\
\hline
\end{tabular}

NB! Only when Spain, Ireland and Italy are excluded does the DDS1 term become significantly negative on the $5 \%$ level in the LABCAP regression. Otherwise, and in the CONCAP regression, the debt service term without the CIP interaction is not significant. 
Table 19: Robustness of parameter estimates to the inclusion of time and the interest rate in the regression, the specification with growth and inflation in levels ${ }^{\mathrm{a}}$. Sample: 1981-1997.

\begin{tabular}{|c|c|c|c|c|}
\hline & $\triangle L A B C A P$ & $\triangle C O N C A P$ & $\triangle L A B C A P$ & $\triangle C O N C A P$ \\
\hline$\Delta \mathrm{BY}_{-1}$ & $-0.047(-0.64)$ & $0.048(1.30)$ & $0.004(0.07)$ & $0.083\left(2.46^{* *}\right)$ \\
\hline$\Delta \mathrm{DS}_{-1}$ & $0.264(0.48)$ & $-0.581\left(-1.92^{* *}\right)$ & $-0.527(-1.03)$ & $-0.816\left(-2.78^{* * *}\right)$ \\
\hline$\Lambda\left(\mathrm{DS}_{-1 *}-\mathrm{CIP}_{-1}\right)$ & $0.351\left(2.22^{* *}\right)$ & $0.301\left(4.17^{* * *}\right)$ & $0.351\left(2.27^{* *}\right)$ & $0.327\left(4.55^{* * *}\right)$ \\
\hline$-\triangle \mathrm{CIP}_{-1}$ & $-0.044(-0.05)$ & $-0.675\left(-1.95^{* *}\right)$ & $0.514(0.55)$ & $-0.601\left(-1.66^{*}\right)$ \\
\hline AUB & $0.845\left(2.63^{* * *}\right)$ & $0.343\left(2.26^{* *}\right)$ & $0.258(0.79)$ & $-0.021(-0.11)$ \\
\hline$\triangle \mathrm{GR}$ & $1.003\left(6.80^{* * *}\right)$ & $0.555\left(8.05^{* * *}\right)$ & & \\
\hline${A \mathrm{GR}_{-1}}$ & $0.424\left(3.12^{* * *}\right)$ & $0.190\left(2.71^{* * *}\right)$ & & \\
\hline GR & & & $0.658\left(3.97^{* * *}\right)$ & $0.345\left(3.78^{* * *}\right)$ \\
\hline $\mathrm{GR}_{-1}$ & & & $-1.217\left(-8.82^{* * *}\right)$ & $-0.636\left(-8.91^{* * *}\right)$ \\
\hline$\triangle \mathrm{INFL}$ & $-0.693\left(-3.41^{* * *}\right)$ & $-0.104(-1.18)$ & & \\
\hline$\Delta \mathrm{INFL}_{-1}$ & $-0.641\left(-3.79^{* * *}\right)$ & $-0.044(-0.60)$ & & \\
\hline INFL & & & $-0.776\left(-4.16^{* * *}\right)$ & $-0.184\left(-2.00^{* *}\right)$ \\
\hline INFL $_{-1}$ & & & $0.409\left(2.33^{* *}\right)$ & $0.164\left(1.92^{*}\right)$ \\
\hline MAAS & $-0.633(-0.54)$ & $-0.118(-0.22)$ & $-0.768(-1.15)$ & $-0.271(-0.79)$ \\
\hline Time & $0.074(0.59)$ & $-0.057(-1.02)$ & & \\
\hline AIRS & $-0.043(-0.28)$ & $-0.226\left(-3.17^{* * *}\right)$ & & \\
\hline DW & 2.29 & 2.24 & & \\
\hline
\end{tabular}

a: debt to GDP, debt service to GDP and unemployment are included in first differences

Table 20. Robustness of parameter estimates to the specification: Estimated in LEVELS including the lagged explanatory variable and a country specific linear time trend. Sample: 1981-1997.

\begin{tabular}{|ccc|}
\hline & LABCAP & CONCAP \\
\hline LAG-DEP & $0.497\left(11.7^{* * *}\right)$ & $0.414\left(10.1^{* * *}\right)$ \\
\hline BY $_{-1}$ & $0.051(0.79)$ & $0.095\left(3.18^{* * *}\right)$ \\
\hline DS1 $_{-1}$ & $-0.418(-0.82)$ & $-0.598\left(-2.44^{* *}\right)$ \\
DS1 $_{-1 *}$ CIP $_{-1}$ & $0.487\left(3.36^{* * *}\right)$ & $0.178\left(2.69^{* * *}\right)$ \\
\hline CIP $_{-1}$ & $-0.860(-0.89)$ & $0.136(0.33)$ \\
\hline UB & $0.952\left(3.97^{* * *}\right)$ & $0.625\left(5.58^{* * *}\right)$ \\
\hline GR & $0.897\left(7.36^{* * *}\right)$ & $0.477\left(8.44^{* * *}\right)$ \\
\hline GR $_{-1}$ & $-0.371\left(-3.62^{* * *}\right)$ & $-0.167\left(-2.92^{* * *}\right)$ \\
\hline INFL $_{\text {INFL }}$ & $-0.476\left(-2.60^{* * *}\right)$ & $0.034(0.41)$ \\
\hline MAAS & $0.211(1.22)$ & $0.093(1.23)$ \\
\hline
\end{tabular}


Table 21. The percentage point change in the effective labor to capital tax ratio due to the country specific average DS and the country specific fall in the CIP between 1985 and $1999^{\mathrm{b}}$.

\begin{tabular}{|c|c|c|c|}
\hline $\begin{array}{c}\text { \%-point change in } \\
L A B C A P\end{array}$ & $b^{a}=0.429$ & $b=0.332$ & $b=0.688$ \\
\hline Austria & 3.12 & 2.41 & 5.00 \\
\hline Belgium & 1.07 & 0.83 & 1.72 \\
\hline Denmark & 0.62 & 0.48 & 0.99 \\
\hline Spain & 4.34 & 3.36 & 6.95 \\
\hline France & 1.25 & 0.97 & 2.01 \\
\hline Ireland & 0.47 & 0.36 & 0.76 \\
\hline Italy & 4.95 & 3.83 & 7.93 \\
\hline The Netherlands & 0.34 & 0.26 & 0.54 \\
\hline Portugal & 6.28 & 4.86 & 10.07 \\
\hline Sweden & 0.48 & 0.37 & 0.77 \\
\hline United Kingdom & 0.01 & 0.01 & 0.02 \\
\hline $\begin{array}{c}\text { \%-point change in } \\
\text { CONCAP }\end{array}$ & $b^{a}=0.317$ & $b=0.215$ & $b=0.356$ \\
\hline Austria & 2.30 & 1.56 & 2.59 \\
\hline Belgium & 0.79 & 0.54 & 0.89 \\
\hline Denmark & 0.46 & 0.31 & 0.51 \\
\hline Spain & 3.20 & 2.17 & 3.60 \\
\hline France & 0.93 & 0.63 & 1.04 \\
\hline Ireland & 0.35 & 0.24 & 0.39 \\
\hline Italy & 3.65 & 2.48 & 4.10 \\
\hline The Netherlands & 0.25 & 0.17 & 0.28 \\
\hline Portugal & 4.64 & 3.15 & 5.21 \\
\hline Sweden & 0.35 & 0.24 & 0.40 \\
\hline United Kingdom & 0.01 & 0.01 & 0.01 \\
\hline
\end{tabular}

a) The first row contains the percentage points change in the effective labor or consumption to capital tax ratio due to the average amount of debt service during 1985 to 1999 due to the country specific fall in CIP between 1985 and 1999. The two other rows show the same number for the lowest and the highest parameter estimates for the effect of the interaction of debt service and the CIP on the effective tax ratios found in the robustness analysis.

b) the CIP is only available back to 1985 for BE, IT, ES, FR, NL and SE. For UK, the fall in CIP is calculated between 1986 and 1999, for AT and DK it is change between 1987 and 1999, for IE 1990 to 1999 and for PT 1992 to 1999 . DE is excluding since the change in the CIP is assumed zero. Greece is excluded since only 3 years of the CIP were available.

Table 22: Summary of the main findings of the panel regressions ${ }^{\mathrm{a}}$

\begin{tabular}{|c|c|c|c|c|c|c|}
\hline & $\begin{array}{c}H 1: \\
\triangle T A X / G D P\end{array}$ & $\begin{array}{c}H 2: \\
\triangle E X P / G D P\end{array}$ & $\begin{array}{c}\text { H3: } \\
\text { ATAX/GDP }\end{array}$ & $\begin{array}{c}H 4: \\
\text { AEXP/GDP }\end{array}$ & $\begin{array}{c}\text { H5: } \\
\text { ALABCAP }\end{array}$ & $\begin{array}{c}\text { H6: } \\
\text { ACONCAP }\end{array}$ \\
\hline $\operatorname{ADS1}_{-1}$ & $\begin{array}{c}0.200 \\
(0.00,0.348)\end{array}$ & $\begin{array}{c}-0.366 \\
(-1.00,-0.197)\end{array}$ & $\begin{array}{c}0.431 \\
(0.383,0.431)\end{array}$ & $\begin{array}{c}-0.257 \\
(-0.301,-0.186)\end{array}$ & - & - \\
\hline $\boldsymbol{A}\left(\mathrm{DS}_{-1} *-\mathrm{CIP}_{-1}\right)$ & & & - & $\begin{array}{c}-0.086 \\
(-0.125,-0.049)\end{array}$ & $\begin{array}{c}0.429 \\
(0.332,0.688)\end{array}$ & $\begin{array}{c}0.317 \\
(0.215,0.356)\end{array}$ \\
\hline$-A_{C I P}$ & & & - & $\begin{array}{c}0.334 \\
(0.334,0.364)\end{array}$ & - & $\begin{array}{c}-0.745 \\
(-0.745,-0.601)\end{array}$ \\
\hline
\end{tabular}

a) Numbers in parentheses are the upper and lower parameter estimates found in the robustness analysis. Only significant and robust parameter estimates are reported. - means that the parameter estimate is not significant in the basic regression. The parameter estimates in bold are the ones relevant for the hypothesis tested. 


\section{Grafs}
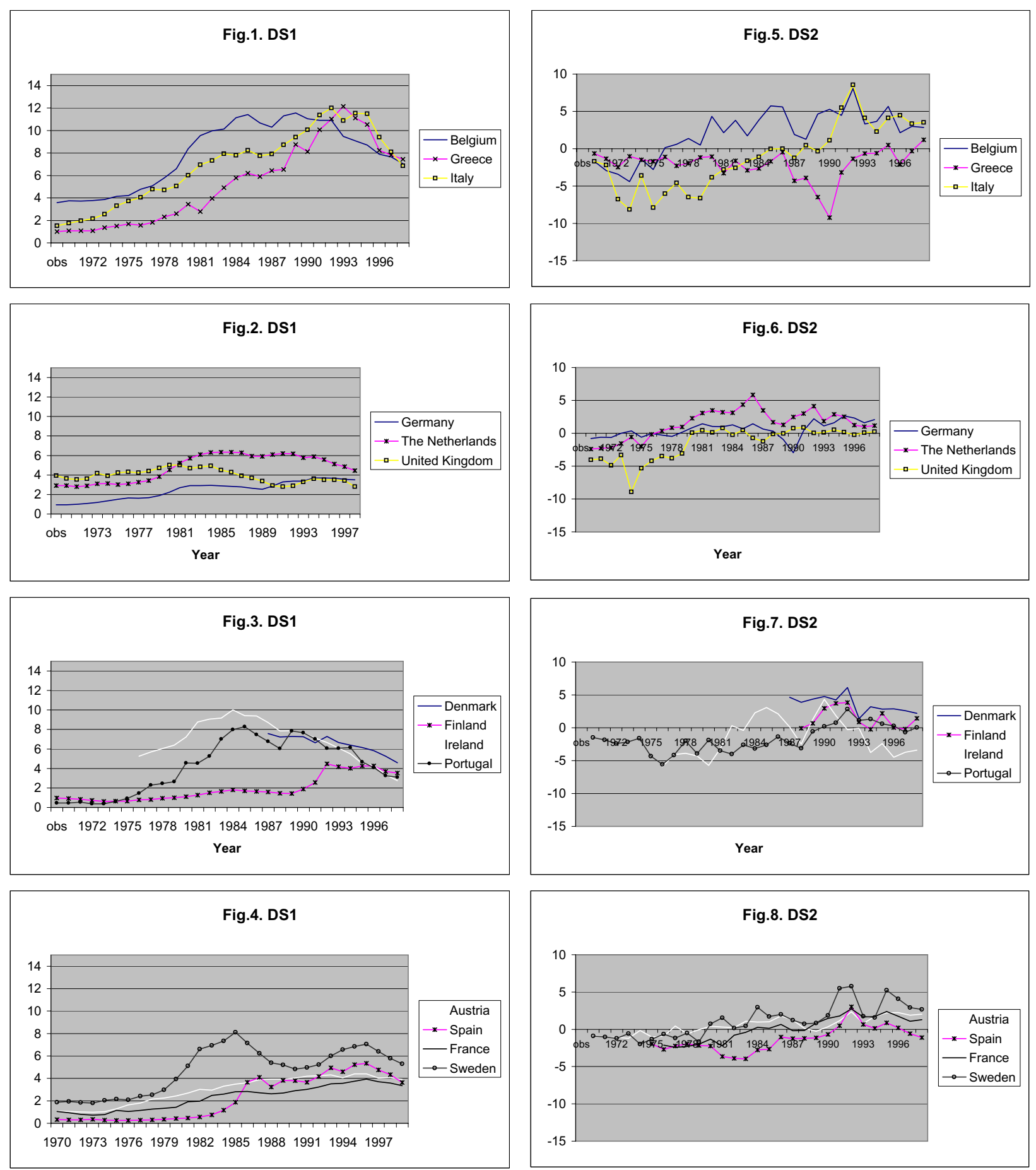

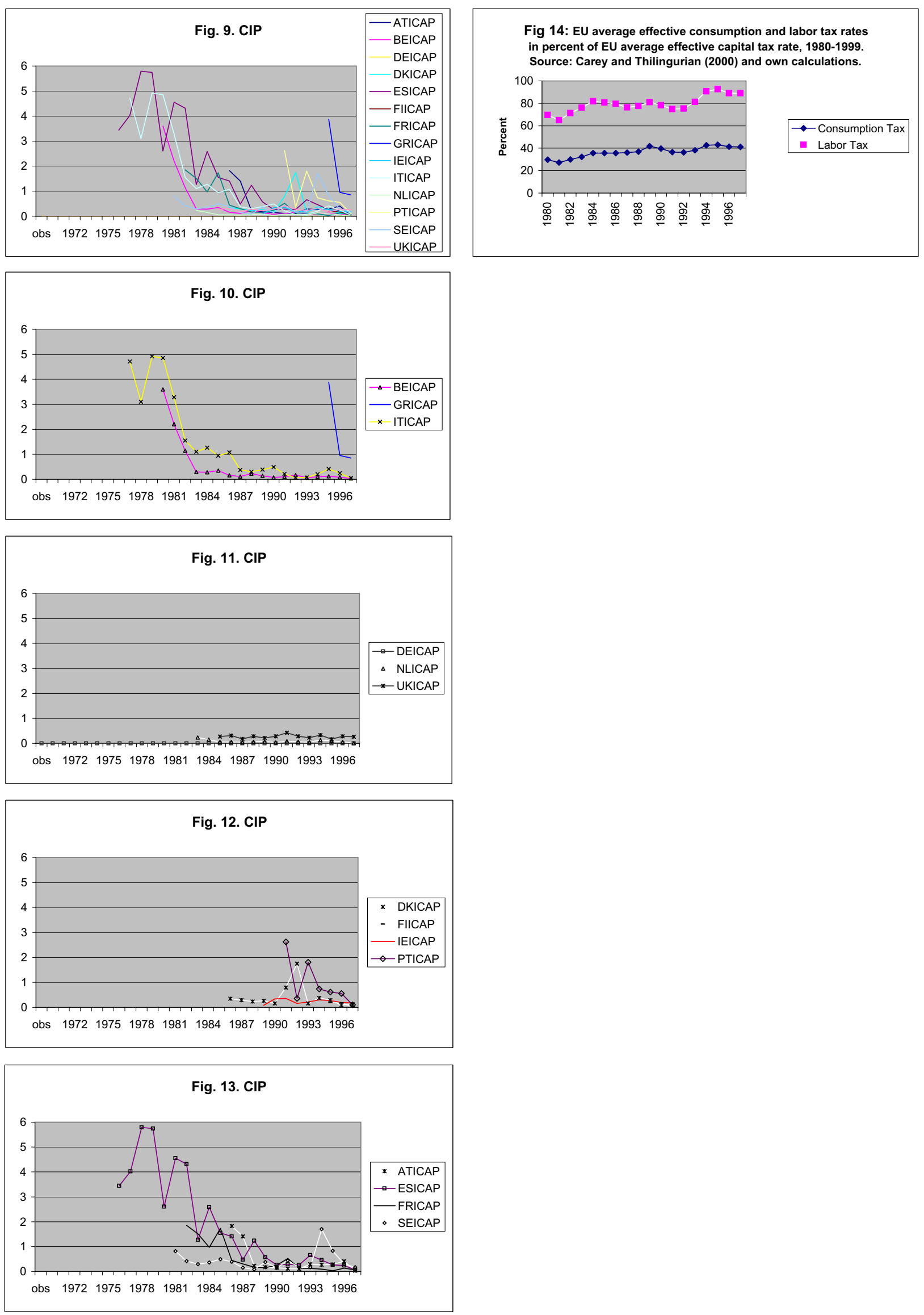


\section{European Central Bank Working Paper Series}

For a complete list of Working Papers published by the ECB, please visit the ECB's website (http://www.ecb.int).

II 3 "Financial frictions and the monetary transmission mechanism: theory, evidence and policy implications” by C. Bean, J. Larsen and K. Nikolov, January 2002.

I 14 "Monetary transmission in the euro area: where do we stand?" by I. Angeloni, A. Kashyap, B. Mojon, D. Terlizzese, January 2002.

II5 "Monetary policy rules, macroeconomic stability and inflation: a view from the trenches" by A. Orphanides, December 2001 .

I 16 "Rent indices for housing in West Germany 1985 to 1998" by J. Hoffmann and C. Kurz., January 2002.

117 "Hedonic house prices without characteristics: the case of new multiunit housing" by O. Bover and P. Velilla, January 2002.

I 8 "Durable goods, price indexes and quality change: an application to automobile prices in Italy, I988-1998” by G. M. Tomat, January 2002.

I 19 "Monetary policy and the stock market in the euro area" by N. Cassola and C. Morana, January 2002.

120 "Learning stability in economics with heterogenous agents" by S. Honkapohja and K. Mitra, January 2002.

121 "Natural rate doubts" by A. Beyer and R. E. A. Farmer, February 2002.

122 "New technologies and productivity growth in the euro area" by F. Vijselaar and R. Albers, February 2002.

123 "Analysing and combining multiple credit assessments of financial institutions" by E. Tabakis and A. Vinci, February 2002.

124 "Monetary policy, expectations and commitment" by G. W. Evans and S. Honkapohja, February 2002.

I25 “Duration, volume and volatility impact of trades" by S. Manganelli, February 2002.

126 "Optimal contracts in a dynamic costly state verification model" by C. Monnet and E. Quintin, February 2002.

127 "Performance of monetary policy with internal central bank forecasting" by S. Honkapohja and K. Mitra, February 2002.

128 "Openness, imperfect exchange rate pass-through and monetary policy" by F. Smets and R. Wouters, February 2002. 
129 "Non-standard central bank loss functions, skewed risks, and certainty equivalence" by A. al-Nowaihi and L. Stracca, March 2002.

130 "Harmonized indexes of consumer prices: their conceptual foundations" by E. Diewert, March 2002.

I3I "Measurement bias in the HICP: what do we know, and what do we need to know?" by M. A. Wynne and D. Rodríguez-Palenzuela, March 2002.

132 "Inflation dynamics and dual inflation in accession countries: a "new Keynesian" perspective” by O. Arratibel, D. Rodríguez-Palenzuela and C. Thimann, March 2002.

133 "Can confidence indicators be useful to predict short term real GDP growth?" by A. Mourougane and M. Roma, March 2002.

134 "The cost of private transportation in the Netherlands, 1992-1999" by B. Bode and J. Van Dalen, March 2002.

135 "The optimal mix of taxes on money, consumption and income" by F. De Fiore and P. Teles, April 2002.

I36 "Retail bank interest rate pass-through: the new evidence at the euro area level" by G. de Bondt, April 2002.

137 "Equilibrium bidding in the eurosystem's open market operations" by U. Bindseil, April 2002.

138 "New" views on the optimum currency area theory: what is EMU telling us?" by F. P. Mongelli, April 2002.

139 “On currency crises and contagion” by M. Fratzscher, April 2002.

I 40 "Price setting and the steady-state effects of inflation" by M. Casares, May 2002.

I4I “Asset prices and fiscal balances” by F. Eschenbach and L. Schuknecht, May 2002.

142 "Modelling the daily banknotes in circulation in the context of the liquidity management of the European Central Bank”, by A. Cabrero, G. Camba-Mendez, A. Hirsch and F. Nieto, May 2002.

143 “A non-parametric method for valuing new goods”, by I. Crawford, May 2002.

144 "A failure in the measurement of inflation: results from a hedonic and matched experiment using scanner data", by M. Silver and S. Heravi, May 2002.

145 "Towards a new early warning system of financial crises", by M. Fratzscher and M. Bussiere, May 2002.

I 46 “Competition and stability - what's special about banking?”, by E. Carletti and P. Hartmann, May 2002. 
147 "Time-to-build approach in a sticky price, stricky wage optimizing monetary model, by M. Casares, May 2002.

148 "The functional form of yield curves" by V. Brousseau, May 2002.

149 "The Spanish block of the ESCB-multi-country model" by A. Estrada and A. Willman, May 2002.

150 "Equity and bond market signals as leading indicators of bank fragility" by R. Gropp, J. Vesala and G. Vulpes, June 2002.

I5I “G-7 inflation forecasts" by F. Canova, June 2002.

152 "Short-term monitoring of fiscal policy discipline" by G. Camba-Mendez and A. Lamo, June 2002.

153 "Euro area production function and potential output: a supply side system approach" by A. Willman, June 2002.

I54 "The euro bloc, the dollar bloc and the yen bloc: how much monetary policy independence can exchange rate flexibility buy in an interdependent world?" by M. Fratzscher, June 2002.

155 "Youth unemployment in the OECD: demographic shifts, labour market institutions, and macroeconomic shocks” by J. F. Jimeno and D. Rodriguez-Palenzuela, June 2002.

I56 "Identifying endogenous fiscal policy rules for macroeconomic models" by J. J. Perez, and P. Hiebert, July 2002.

157 "Bidding and performance in repo auctions: evidence from ECB open market operations" by K. G. Nyborg, U. Bindseil and I. A. Strebulaev, July 2002.

158 "Quantifying Embodied Technological Change” by P. Sakellaris and D. J. Wilson, July 2002.

159 “Optimal public money” by C. Monnet, July 2002.

160 "Model uncertainty and the equilibrium value of the real effective euro exchange rate" by C. Detken, A. Dieppe, J. Henry, C. Marin and F. Smets, July 2002.

16I "The optimal allocation of risks under prospect theory" by L. Stracca, July 2002.

162 "Public debt asymmetries: the effect on taxes and spending in the European Union" by S. Krogstrup, August 2002. 